\title{
Packing polymorphism of dicarbonyl-[2-(phenylamino)pent-3-en-4-onato]rhodium(I)
}

Hendrik Ferreira, ${ }^{\mathrm{a}}$ Marrigje Marianne Conradie, ${ }^{\mathrm{a}}$ Petrus H.van Rooyen, ${ }^{\mathrm{b}}$ Jeanet Conradie ${ }^{\mathrm{a}, *}$

a Department of Chemistry, PO Box 339, University of the Free State, 9300 Bloemfontein, Republic of South Africa.

${ }^{b}$ Department of Chemistry, University of Pretoria, Private Bag X20, Hatfield, 0028, South Africa.

*Contact author details:

Name: Jeanet Conradie

Tel: $+27-51-4012194$

Fax: $+27-51-4017295$

E-mail: conradj@ufs.ac.za

\section{Keywords}

Rhodium; DFT; dicarbonyl; metal-metal interaction; packing

\section{Graphical abstract}
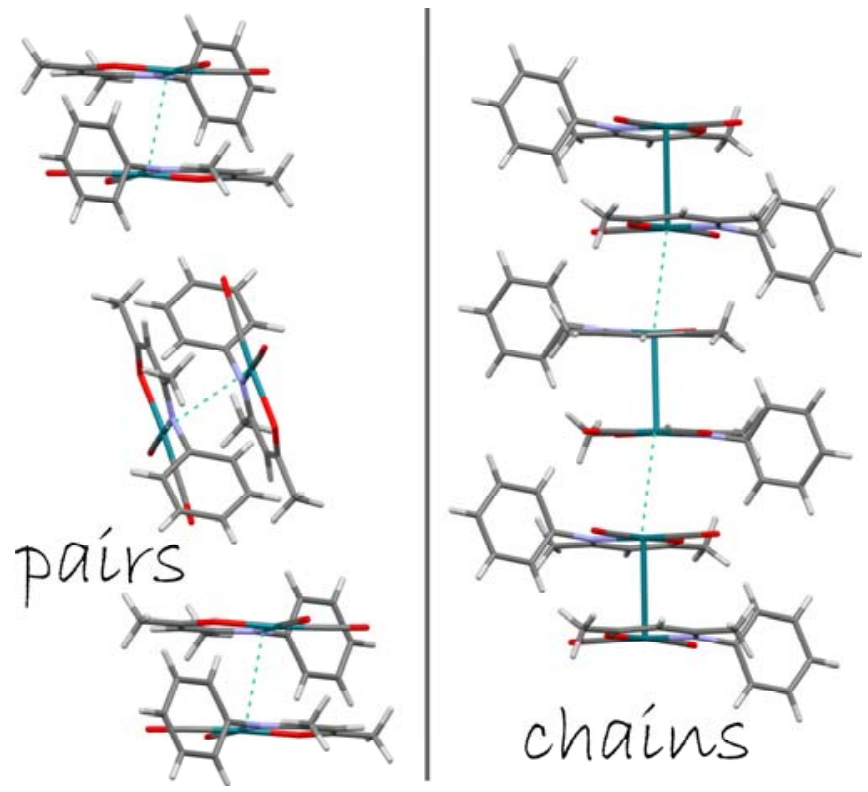


\title{
Synopsis
}

Structure and packing of $\left[\mathrm{Rh}\left(\mathrm{CH}_{3} \mathrm{COCHCN}(\mathrm{Ph}) \mathrm{CH}_{3}\right)(\mathrm{CO})_{2}\right]$.

\section{Highlights}

Packing in pairs, versus in linear arrays of $\left[\mathrm{Rh}\left(\mathrm{CH}_{3} \mathrm{COCHCN}(\mathrm{Ph}) \mathrm{CH}_{3}\right)(\mathrm{CO})_{2}\right]$

Sigma-sigma interaction of rhodium $d_{z^{2}}$ molecular orbitals

AIM bonding paths indicating intermolecular metallophilic $\mathrm{Rh}-\mathrm{Rh}$ interactions

NBO shows $\operatorname{LP}\left(\operatorname{Rh} d_{z^{2}}\right)-\mathrm{LP} *\left(\mathrm{Rh} p_{z}\right)$ interaction

Intermolecular rhodium-rhodium distance decreases with temperature

\begin{abstract}
Depending on the crystallization conditions, the interaction between the rhodium metal centres of the separate $\left[\mathrm{Rh}\left(\mathrm{CH}_{3} \mathrm{COCHCN}(\mathrm{Ph}) \mathrm{CH}_{3}\right)(\mathrm{CO})_{2}\right]$ molecular units, as described by the interplanar separation and lateral shift of two of the units, leads to packing polymorphism of $\left[\mathrm{Rh}\left(\mathrm{CH}_{3} \mathrm{COCHCN}(\mathrm{Ph}) \mathrm{CH}_{3}\right)(\mathrm{CO})_{2}\right]$, which means the same molecule crystallises in different fashions, resulting in different polymorphs $(\alpha$ and $\beta$ ), with a difference in crystal packing. Six different sets of solid state single crystal data of $\left[\mathrm{Rh}\left(\mathrm{CH}_{3} \mathrm{COCHCN}(\mathrm{Ph}) \mathrm{CH}_{3}\right)(\mathrm{CO})_{2}\right]$, show that this complex is polymorphic, forming dinuclear units that either stack in wire-like chains with weak metallophilic rhodium-rhodium interactions ( $\beta$-polymorph), or with packing of the dinuclear units that does not result in rhodium-rhodium chains ( $\alpha$-polymorph). A DFT study on the intermolecular interactions in different dinuclear $\left[\mathrm{Rh}\left(\mathrm{CH}_{3} \mathrm{COCHCN}(\mathrm{Ph}) \mathrm{CH}_{3}\right)(\mathrm{CO})_{2}\right]_{2}$ models, using different DFT methods, provides an understanding on a molecular level of the rhodium-rhodium and other inter-molecular interactions between the two separate $\left[\mathrm{Rh}\left(\mathrm{CH}_{3} \mathrm{COCHCN}(\mathrm{Ph}) \mathrm{CH}_{3}\right)(\mathrm{CO})_{2}\right]$ molecules in the dinuclear unit.
\end{abstract}

\section{Introduction}

Polymorphism [1] has been defined by McCrone in 1965 as "a solid crystalline phase of a given compound resulting from the possibility of at least two different arrangements of the molecules of 
that compound in the solid state" [2]. A few years later, Rosenstein and Lamy (1969) simplified the definition to "when a substance can exist in more than one crystalline state it is said to exhibit polymorphism" [3]. Polymorphs are also described as "isomers at the individual crystal level in which the same molecule or salt crystallises in different fashions, which frequently, but not necessarily, result in differences in the space group and the cell dimensions", sometimes leading to different arrangements (packing) of the molecules in the solid state [4]. When polymorphism exists as a result of differences in crystal packing, it is called packing polymorphism. It has been observed that the molecules of different $\left[\mathrm{Rh}(\beta\right.$-diketonato $\left.)(\mathrm{CO})_{2}\right]$ complexes in the solid state, either pack in separate dinuclear $\left[\mathrm{Rh}(\beta \text {-diketonato })(\mathrm{CO})_{2}\right]_{2}$ dimeric units $[5,6,7]$, while others of these complexes pack in dinuclear units which form extended linear wire-like chains of rhodium atoms $[8,9,10,11]$. The extended metal-metal interactions along the linear chains in the latter case, have been described as resulting from the overlap of the filled $d_{z^{2}}$ orbitals and the empty $p_{z}$ orbitals that lie along the direction of the metal-metal axis [12]. Similarly to the latter, it has been shown recently that crystals of the complex $\left[\mathrm{Rh}\left(\mathrm{CH}_{3} \mathrm{COCHCN}(\mathrm{Ph}) \mathrm{CH}_{3}\right)(\mathrm{CO})_{2}\right]$ (dicarbonyl-[2(phenylamino)pent-3-en-4-onato]rhodium(I)) [13] (see Figure 1), in the solid state also pack in linear chains of consecutive unit cells along the intermolecular rhodium-metal axis in a wire-like structure (called the $\beta$-polymorph), while a related molecule of dicarbonyl-(4-((2,6dichlorophenyl)imino)pent-2-en-2-olato)-rhodium did not show any inter-molecular rhodiumrhodium interaction in the solid state at all [13]. In this contribution we present an additional packing polymorphism (the $\alpha$-polymorph) of the same $\left[\mathrm{Rh}\left(\mathrm{CH}_{3} \mathrm{COCHCN}(\mathrm{Ph}) \mathrm{CH}_{3}\right)(\mathrm{CO})_{2}\right]$ molecule (as in Figure 1), complemented by a DFT study on the inter-molecular rhodium-rhodium interactions in four different dinuclear $\left[\mathrm{Rh}\left(\mathrm{CH}_{3} \mathrm{COCHCN}(\mathrm{Ph}) \mathrm{CH}_{3}\right)(\mathrm{CO})_{2}\right]_{2}$ models.

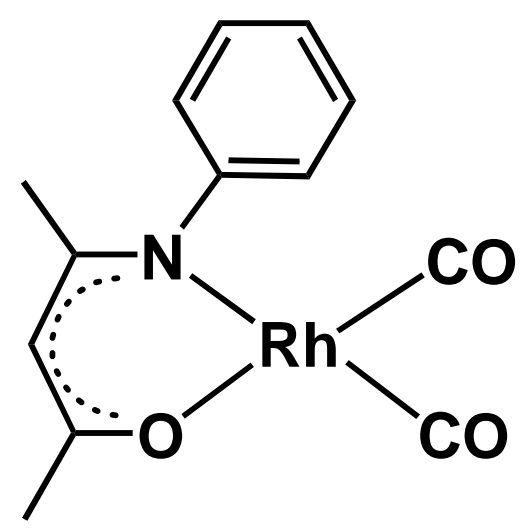

Figure 1: Structure of $\left[\mathrm{Rh}\left(\mathrm{CH}_{3} \mathrm{COCHCN}(\mathrm{Ph}) \mathrm{CH}_{3}\right)(\mathrm{CO})_{2}\right]$. 


\section{Experimental}

\subsection{Synthesis}

Reagents were obtained from Sigma-Aldrich. Solid reagents employed in preparations were used directly without further purification. Solvents were distilled prior to use. Di- $\mu$-chlorotetracarbonyldirhodium(I) was obtained from Sigma-Aldrich.

\subsection{1 $\left[\mathrm{CH}_{3} \mathrm{COCHCN}(\mathrm{HPh}) \mathrm{CH}_{3}\right]$}

The ligand $\left[\mathrm{CH}_{3} \mathrm{COCHCN}(\mathrm{HPh}) \mathrm{CH}_{3}\right]$ was synthesised using published methods $[14,15,16,17]$ with slight modifications. Acetylacetone $(5 \mathrm{~g}, 5.2 \mathrm{ml})$ was placed in a round bottom flask outfitted with a condenser for refluxing. Aniline $(6.9763 \mathrm{~g}, 7 \mathrm{ml})$ and concentrated hydrochloric acid (5 g, $4.3 \mathrm{ml})$ was added to the flask whilst stirring and the mixture was brought to reflux for 5 hours. Diethyl ether was added to the mixture and then placed in the fridge $\left(-5^{\circ} \mathrm{C}\right)$. The yellow crystalline precipitate was filtered and washed with cold diethyl ether and recrystallised.

Yield $=50 \%$. ${ }^{1} \mathrm{H}$ NMR: 12.493 ppm (s, O-H); 7.388 ppm - 7.114 ppm (m, $\left.\mathrm{C}_{6} \mathrm{H}_{5}-\mathrm{N}\right) ; 5.208$ ppm (s, $\mathrm{C}-\mathrm{H}) ; 2.122 \mathrm{ppm}\left(\mathrm{s}, \mathrm{CH}_{3}-\mathrm{CN}\right) ; 2.014$ ppm (s, $\left.\mathrm{CH}_{3}-\mathrm{CO}\right)$

\subsection{2 $\left[\mathrm{Rh}\left(\mathrm{CH}_{3} \mathrm{COCHCN}(\mathrm{Ph}) \mathrm{CH}_{3}\right)(\mathrm{CO})_{2}\right]$}

The complex $\left[\mathrm{Rh}\left(\mathrm{CH}_{3} \mathrm{COCHCN}(\mathrm{Ph}) \mathrm{CH}_{3}\right)(\mathrm{CO})_{2}\right]$ was synthesised using published methods with slight modifications [18]. The metal, di- $\mu$-chloro-tetracarbonyldirhodium(I) (0.05 g, 0.1286 mmole), was dissolved in methanol (5 ml). The ligand, [ $\left.\mathrm{CH}_{3} \mathrm{COCHCNHPhCH}_{3}\right](0.2572 \mathrm{mmole})$, also dissolved in methanol $(2 \mathrm{ml})$ was added dropwise during 10 minutes whilst stirring. The mixture was left to stir for 1 hour. The mixture was then extracted with n-hexane until the n-hexane solvent became clear. The solvents were combined and evaporated under reduced pressure. The precipitated solid was collected and recrystallised, either from n-hexane at $-5{ }^{\circ} \mathrm{C}$, or from DCM at room temperature $\left(25^{\circ} \mathrm{C}\right)$.

Yield $=78 \% .{ }^{1} \mathrm{H}$ NMR: $7.388 \mathrm{ppm}-7.061 \mathrm{ppm}\left(\mathrm{m}, \mathrm{C}_{6} \mathrm{H}_{5}-\mathrm{N}\right) ; 5.298 \mathrm{ppm}(\mathrm{s}, \mathrm{C}-\mathrm{H}) ; 2.195 \mathrm{ppm}(\mathrm{s}$, $\left.\mathrm{CH}_{3}-\mathrm{CN}\right) ; 2.141 \mathrm{ppm}\left(\mathrm{s}, \mathrm{CH}_{3}-\mathrm{CO}\right) . v_{\mathrm{CO}}: 2059 \mathrm{~cm}^{-1} ; 1998 \mathrm{~cm}^{-1} . \mathrm{UV} / \mathrm{Vis}\left(\mathrm{CHCl}_{3}\right): \lambda_{\max }=329 \mathrm{~nm}(\varepsilon$ $\left.=5102 \mathrm{~mol}^{-1} \mathrm{dm}^{+3} \mathrm{~cm}^{-1}\right), 265 \mathrm{~nm}\left(\varepsilon=6497 \mathrm{~mol}^{-1} \mathrm{dm}^{+3} \mathrm{~cm}^{-1}\right)$.

\subsection{Crystal structure analysis}

The solid state crystal data of two crystals, obtained under different crystallisation conditions, collected at three different temperatures, for two different crystalline forms of $\left[\mathrm{Rh}\left(\mathrm{CH}_{3} \mathrm{COCHCN}(\mathrm{Ph}) \mathrm{CH}_{3}\right)(\mathrm{CO})_{2}\right]$, is presented here. The first crystalline form, labelled the $\alpha$ polymorph, was obtained from a solution of n-hexane at $-5{ }^{\circ} \mathrm{C}$. The second crystalline form, 
labelled the $\beta$-polymorph, was crystallised from a solution of DCM at room temperature. Data for both crystals was collected, both at RT and at $150 \mathrm{~K}$ for each of these two crystalline forms ( $\alpha$ - and $\beta$-polymorphs), on a Bruker D8 Venture kappa geometry diffractometer, with duo I $\mu$ s sources, a Photon 100 CMOS detector and APEX II [19] control software, using Quazar multi-layer optics, and monochromated Mo-K $\alpha$ radiation, by means of a combination of $\phi$ and $\omega$ scans. An additional set of data for the $\alpha$-polymorph was collected at $100 \mathrm{~K}$, on a Bruker APEX-II CCD.

Data reduction was performed using SAINT+ [19] and the intensities were corrected for absorption, using SADABS [19]. The five crystal structures were solved by intrinsic phasing, using SHELXTS, and refined by full-matrix least squares, using both SHELXTL+ [20] and SHELXL$2014+[20]$. In the structure refinement, all hydrogen atoms were added in the calculated positions and treated as riding on the atom to which they are attached. All non-hydrogen atoms were refined with anisotropic displacement parameters; all isotropic displacement parameters for hydrogen atoms were calculated as $\left(X \times U_{\text {eq }}\right)$ of the atom to which they are attached, where $X=1.5$ for the methyl hydrogens, and $\mathrm{X}=1.2$ for all other hydrogens. Crystal data, data collections, structure solutions and refinement details for all five crystal structures, are available in the CIF (with CCDC deposit numbers 1548178, 1558071, 1571132, 1571133 and 1571134).

\subsection{Theoretical approach}

Density functional theory (DFT) calculations of this study were performed with the hybrid B3LYP [21,22] functional, as implemented in the Gaussian 09 program package [23]. Geometries of the neutral complexes were optimised in the gas phase, using the $6-311 \mathrm{G}(\mathrm{d}, \mathrm{p})$ basis set on all atoms except rhodium, for which the def2tzvpp [24] (valens electrons) and SDD (core electrons) basis set was used. These B3LYP optimised gas phase structures were used to further conduct a natural bond orbital (NBO) analysis (using the NBO 3.1 module [25] in Gaussian 09), a fragment analysis, as well as an electronic density analysis (using Bader's quantum theory of atoms in molecules (QTAIM) [26,27,28], as implemented in ADF2013 [29,30,31]), at the same level of theory.

The single molecular unit of complex $\left[\mathrm{Rh}\left(\mathrm{CH}_{3} \mathrm{COCHCN}(\mathrm{Ph}) \mathrm{CH}_{3}\right)(\mathrm{CO})_{2}\right]$ was optimised by calculation, as well as the $\left[\mathrm{Rh}\left(\mathrm{CH}_{3} \mathrm{COCHCN}(\mathrm{Ph}) \mathrm{CH}_{3}\right)(\mathrm{CO})_{2}\right]_{2}$ dimeric unit. Further additional single point calculations were done on the coordinates of such a dinuclear unit which were obtained from the solid state crystal structure data of this study ( $\alpha$-polymorph at $150 \mathrm{~K}$ ), as well as on two 
additional dinuclear models, calculated on the coordinates of a dinuclear unit obtained from the solid state crystal structure data of a previous study ( $\beta$-polymorph at $100 \mathrm{~K}$ ), as described in Section 3.2.2. The coordinates of the DFT calculations are given in the Supporting Information.

\section{Results and discussion}

\subsection{X-ray structure}

In this section, crystallographic results are presented of the solid state crystal data of two polymorphs of complex $\left[\mathrm{Rh}\left(\mathrm{CH}_{3} \mathrm{COCHCN}(\mathrm{Ph}) \mathrm{CH}_{3}\right)(\mathrm{CO})_{2}\right]$; see Table 1 and Table 2 (column 2 6). Data for each crystalline structure was repeatedly collected at decreasing temperatures, to determine whether temperature would transform the structure of each polymorph. The two structures were labelled the $\alpha$-polymorph (with space group P $21 / \mathrm{n}$, data collected at $298 \mathrm{~K}, 150 \mathrm{~K}$ and $100 \mathrm{~K}$ ), as well as the $\beta$-polymorph (with space group I2/a, data collected at $298 \mathrm{~K}$ and $150 \mathrm{~K}$ ). These experimental results were then compared to a previously published structure [13] and packing of the same complex ( $\beta$-polymorph with space group I2/a, data collected at $100 \mathrm{~K}$ ); see Table 2 (last column of the $\beta$-polymorphs). Crystals suitable for X-ray diffraction were obtained by slow evaporation from either an $n$-hexane solution at $-5{ }^{\circ} \mathrm{C}$ (to yield the $\alpha$-polymorph), or from a DCM solution at RT (to yield the $\beta$-polymorph). Both polymorphs exhibit the same experimental properties, such as colour or UV/vis, IR and ${ }^{1} \mathrm{H}$ NMR spectra as provided in the experimental section. The different polymorphs seemed to result from different crystallisation conditions (solvent and temperature) and did not transform into one another by cooling, since it was found by crystallography that the space group of a specific polymorph stayed the same upon cooling from 298 K to $150 \mathrm{~K}$ or $100 \mathrm{~K}$; see Table 1. 
Table 1: Crystal data and structure refinement of both the $\alpha$-and $\beta$-polymorphs of complex $\left[\mathrm{Rh}_{(}\left(\mathrm{CH}_{3} \mathrm{COCHCN}(\mathrm{Ph}) \mathrm{CH} 3\right)(\mathrm{CO})_{2}\right]$, collected for two crystals at three different temperatures $(298 \mathrm{~K}, 150 \mathrm{~K}$ and $100 \mathrm{~K})$.

\begin{tabular}{|c|c|c|c|c|c|}
\hline Polymorph & $\alpha$ & $\alpha$ & $\alpha$ & $\beta$ & $\beta$ \\
\hline Empirical formula & $\mathrm{C}_{13} \mathrm{H}_{12} \mathrm{~N} \mathrm{O}_{3} \mathrm{Rh}$ & $\mathrm{C}_{13} \mathrm{H}_{12} \mathrm{~N} \mathrm{O}_{3} \mathrm{Rh}$ & $\mathrm{C}_{13} \mathrm{H}_{12} \mathrm{~N} \mathrm{O}_{3} \mathrm{Rh}$ & $\mathrm{C}_{13} \mathrm{H}_{12} \mathrm{~N} \mathrm{O}_{3} \mathrm{Rh}$ & $\mathrm{C}_{13} \mathrm{H}_{12} \mathrm{~N} \mathrm{O}_{3} \mathrm{Rh}$ \\
\hline Formula weight & 333.15 & 333.15 & 333.15 & 333.15 & 333.15 \\
\hline Temperature & $298(2) \mathrm{K}$ & $150(2) \mathrm{K}$ & $100(2) \mathrm{K}$ & 298(2) K & $150(2) \mathrm{K}$ \\
\hline Wavelength & $0.71073 \AA$ & $0.71073 \AA$ & $0.71073 \AA$ & $0.71073 \AA$ & $0.71073 \AA$ \\
\hline Crystal system & Monoclinic & Monoclinic & Monoclinic & Monoclinic & Monoclinic \\
\hline Space group & $\mathrm{P} 2{ }_{1} / \mathrm{n}$ & $\mathrm{P} 2{ }_{1} / \mathrm{n}$ & $\mathrm{P} 2{ }_{1} / \mathrm{n}$ & I $2 / a$ & I $2 / a$ \\
\hline \multirow{6}{*}{ Unit cell dimensions } & $\mathrm{a}=8.7171(4) \AA$ & $\mathrm{a}=8.5599(4) \AA$ & $a=8.5127(5) \AA$ & $\mathrm{a}=13.6872(10) \AA$ & $\mathrm{a}=13.4204(14) \AA$ \\
\hline & $\mathrm{b}=12.0141(5) \AA$ & $\mathrm{b}=11.9808(6) \AA$ & $\mathrm{b}=11.9666(7) \AA$ & $b=9.3364(16) \AA$ & $\mathrm{b}=9.3030(8) \AA$ \\
\hline & $\mathrm{c}=13.1833(6) \AA$ & $\mathrm{c}=13.1030(7) \AA$ & $\mathrm{c}=13.0725(8) \AA$ & $\mathrm{c}=21.350(3) \AA$ & $\mathrm{c}=21.226(3) \AA$ \\
\hline & $\alpha=90^{\circ}$ & $\alpha=90^{\circ}$ & $\alpha=90^{\circ}$ & $\alpha=90^{\circ}$ & $\alpha=90^{\circ}$ \\
\hline & $\beta=105.6850(10)^{\circ}$ & $\beta=105.775(2)^{\circ}$ & $\beta=105.874(2)^{\circ}$ & $\beta=95.000(4)^{\circ}$ & $\beta=95.817(4)^{\circ}$. \\
\hline & $\gamma=90^{\circ}$ & $\gamma=90^{\circ}$ & $\gamma=90^{\circ}$ & $\gamma=90^{\circ}$ & $\gamma=90^{\circ}$ \\
\hline Volume & $1329.25(10) \AA^{3}$ & $1293.16(11) \AA^{3}$ & $1280.89(13) \AA^{3}$ & $2717.9(6) \AA^{3}$ & $2636.4(5) \AA^{3}$ \\
\hline $\mathrm{Z}$ & 4 & 4 & 4 & 8 & 8 \\
\hline Density (calculated) & $1.665 \mathrm{Mg} / \mathrm{m}^{3}$ & $1.711 \mathrm{Mg} / \mathrm{m}^{3}$ & $1.728 \mathrm{Mg} / \mathrm{m}^{3}$ & $1.628 \mathrm{Mg} / \mathrm{m}^{3}$ & $1.679 \mathrm{Mg} / \mathrm{m}^{3}$ \\
\hline Absorption coefficient & $1.283 \mathrm{~mm}^{-1}$ & $1.319 \mathrm{~mm}^{-1}$ & $1.332 \mathrm{~mm}^{-1}$ & $1.255 \mathrm{~mm}^{-1}$ & $1.294 \mathrm{~mm}^{-1}$ \\
\hline $\mathrm{F}(000)$ & 664 & 664 & 664 & 1328 & 1328 \\
\hline Crystal size & $\begin{array}{l}0.185 \times 0.158 \times 0.148 \\
\mathrm{~mm}^{3}\end{array}$ & $\begin{array}{l}0.185 \times 0.158 \times 0.148 \\
\mathrm{~mm}^{3}\end{array}$ & $\begin{array}{l}0.185 \times 0.158 \times 0.148 \\
\mathrm{~mm}^{3}\end{array}$ & $\begin{array}{l}0.480 \times 0.120 \times 0.110 \\
\mathrm{~mm}^{3}\end{array}$ & $\begin{array}{l}0.480 \times 0.120 \times 0.110 \\
\mathrm{~mm}^{3}\end{array}$ \\
\hline Theta range for data collection & 2.520 to $28.387^{\circ}$ & 2.345 to $25.339^{\circ}$ & 3.014 to $25.349^{\circ}$ & 2.382 to $26.408^{\circ}$ & 2.392 to $28.536^{\circ}$ \\
\hline \multirow[t]{2}{*}{ Index ranges } & $-11<=\mathrm{h}<=11,-$ & $-10<=\mathrm{h}<=10,-$ & $-10<=\mathrm{h}<=10$ & $-17<=\mathrm{h}<=17,-$ & $-17<=\mathrm{h}<=17,-$ \\
\hline & $16<=\mathrm{k}<=16,-17<=1<=17$ & $14<=\mathrm{k}<=14,-15<=1<=15$ & $14<=\mathrm{k}<=14,-15<=1<=15$ & $11<=\mathrm{k}<=11,-26<=1<=26$ & $12<=\mathrm{k}<=12,-28<=1<=28$ \\
\hline Reflections collected & 48660 & 14021 & 49469 & 33261 & 41844 \\
\hline Independent reflections & $3347[\mathrm{R}(\mathrm{int})=0.0335]$ & $2370[\mathrm{R}(\mathrm{int})=0.0252]$ & $2350[\mathrm{R}(\mathrm{int})=0.0182]$ & $2789[\mathrm{R}($ int $)=0.0863]$ & $3342[\mathrm{R}($ int $)=0.0632]$ \\
\hline Completeness to theta $=25.242^{\circ}$ & $100 \%$ & $99.9 \%$ & $99.9 \%$ & $100.0 \%$ & $100.0 \%$ \\
\hline Refinement method & $\begin{array}{l}\text { Full-matrix least-squares } \\
\text { on } \mathrm{F}^{2}\end{array}$ & $\begin{array}{l}\text { Full-matrix least-squares } \\
\text { on } \mathrm{F}^{2}\end{array}$ & $\begin{array}{l}\text { Full-matrix least-squares } \\
\text { on } \mathrm{F}^{2}\end{array}$ & $\begin{array}{l}\text { Full-matrix least-squares } \\
\text { on } \mathrm{F}^{2}\end{array}$ & $\begin{array}{l}\text { Full-matrix least-squares } \\
\text { on } \mathrm{F}^{2}\end{array}$ \\
\hline Data / restraints / parameters & $3347 / 0 / 165$ & $2370 / 0 / 163$ & $2350 / 0 / 165$ & $2789 / 0 / 165$ & $3342 / 0 / 165$ \\
\hline Goodness-of-fit on $\mathrm{F}^{2}$ & 1.041 & 1.043 & 1.134 & 1.013 & 1.040 \\
\hline Final $\mathrm{R}$ indices $[\mathrm{I}>2 \operatorname{sigma}(\mathrm{I})]$ & $\begin{array}{l}\mathrm{R} 1=0.0214, \mathrm{wR} 2= \\
0.0591\end{array}$ & $\begin{array}{l}\mathrm{R} 1=0.0177, \mathrm{wR} 2= \\
0.0440\end{array}$ & $\begin{array}{l}\mathrm{R} 1=0.0146, \mathrm{wR} 2= \\
0.0375\end{array}$ & $\begin{array}{l}\mathrm{R} 1=0.0344, \mathrm{wR} 2= \\
0.0582\end{array}$ & $\begin{array}{l}\mathrm{R} 1=0.0232, \mathrm{wR} 2= \\
0.0449\end{array}$ \\
\hline $\mathrm{R}$ indices (all data) & $\begin{array}{l}\mathrm{R} 1=0.0318, \mathrm{wR} 2= \\
0.0668\end{array}$ & $\begin{array}{l}\mathrm{R} 1=0.0 .021, \mathrm{wR} 2= \\
0.0456\end{array}$ & $\begin{array}{l}\mathrm{R} 1=0.0152, \mathrm{wR} 2= \\
0.0379\end{array}$ & $\begin{array}{l}\mathrm{R} 1=0.0714, \mathrm{wR} 2= \\
0.0662\end{array}$ & $\begin{array}{l}\mathrm{R} 1=0.0376, \mathrm{wR} 2= \\
0.0479\end{array}$ \\
\hline Extinction coefficient & $\mathrm{n} / \mathrm{a}$ & $\mathrm{n} / \mathrm{a}$ & $\mathrm{n} / \mathrm{a}$ & $\mathrm{n} / \mathrm{a}$ & $\mathrm{n} / \mathrm{a}$ \\
\hline Largest diff. peak and hole & 0.348 and -0.470 e. $\AA^{-3}$ & 0.499 and -0.183 e. $\AA^{-3}$ & 0.260 and -0.494 e. $\AA^{-3}$ & 0.472 and -0.463 e. $\AA^{-3}$ & 0.410 and -0.439 e..$\AA^{-3}$ \\
\hline
\end{tabular}


Table 2: Selected geometrical data (bond lengths in $\AA$ and bond angles in degrees) of complex $\left[\mathrm{Rh}_{(}\left(\mathrm{CH}_{3} \mathrm{COCHCN}_{(\mathrm{Ph}) \mathrm{CH}}\right)(\mathrm{CO})_{2}\right]$, obtained for both its $\alpha$ - and $\beta$-polymorphs, as well as the optimized DFT calculated data. Data for the two crystals from this study (columns 2 - 6) is compared to the corresponding crystallographic data of a previously published $\beta$-polymorph, collected at $100 \mathrm{~K}$ [13] (column 7). Atom numbering is shown in Figure 2.

\begin{tabular}{|c|c|c|c|c|c|c|c|c|c|}
\hline Polymorph & $\alpha$-polymorp & & & $\beta$-polymor & & & difference & DFT & max difference \\
\hline Temperature & $298 \mathrm{~K}$ & $150 \mathrm{~K}$ & $100 \mathrm{~K}$ & $298 \mathrm{~K}$ & $150 \mathrm{~K}$ & $100 \mathrm{~K}$ & $\begin{array}{l}\text { experimental } \\
\text { parameter }\end{array}$ & $\begin{array}{l}\text { optimised } \\
\text { molecule }\end{array}$ & $\begin{array}{l}\text { experimental } \\
\text { parameter }\end{array}$ \\
\hline $\mathrm{Rh}(1)-\mathrm{C}(1)$ & $1.841(2)$ & $1.847(2)$ & $1.8439(17)$ & $1.827(4)$ & $1.844(2)$ & $1.841(3)$ & 0.020 & 1.855 & 0.028 \\
\hline $\mathrm{Rh}(1)-\mathrm{C}(2)$ & $1.866(2)$ & $1.870(2)$ & $1.8709(17)$ & $1.857(4)$ & $1.868(2)$ & $1.866(2)$ & 0.014 & 1.878 & 0.021 \\
\hline $\mathrm{Rh}(1)-\mathrm{O}(3)$ & $2.0187(14)$ & $2.0239(13)$ & $2.0251(11)$ & $2.022(2)$ & $2.0312(13)$ & $2.032(2)$ & 0.013 & 2.040 & 0.021 \\
\hline $\mathrm{Rh}(1)-\mathrm{N}(1)$ & $2.0501(17)$ & $2.0540(16)$ & $2.0557(13)$ & $2.054(3)$ & $2.0596(15)$ & $2.058(2)$ & 0.010 & 2.092 & 0.042 \\
\hline $\mathrm{O}(3)-\mathrm{C}(3)$ & $1.284(3)$ & $1.292(2)$ & $1.291(2)$ & $1.282(4)$ & $1.289(2)$ & $1.294(2)$ & 0.012 & 1.280 & 0.014 \\
\hline $\mathrm{N}(1)-\mathrm{C}(5)$ & $1.314(2)$ & $1.321(2)$ & $1.320(2)$ & $1.318(4)$ & $1.320(2)$ & $1.318(3)$ & 0.007 & 1.330 & 0.016 \\
\hline $\mathrm{N}(1)-\mathrm{C}(6)$ & $1.448(3)$ & $1.443(2)$ & $1.444(2)$ & $1.437(4)$ & $1.441(2)$ & $1.448(3)$ & 0.011 & 1.439 & 0.009 \\
\hline$C(4)-C(5)$ & $1.419(3)$ & $1.417(3)$ & $1.418(2)$ & $1.395(5)$ & $1.408(3)$ & $1.410(3)$ & 0.024 & 1.412 & 0.017 \\
\hline$C(3)-C(4)$ & $1.357(3)$ & $1.372(3)$ & $1.374(2)$ & $1.376(5)$ & $1.380(3)$ & $1.381(3)$ & 0.024 & 1.390 & 0.033 \\
\hline $\mathrm{C}(1)-\mathrm{Rh}(1)-\mathrm{C}(2)$ & $86.79(10)$ & $87.03(9)$ & $86.98(7)$ & $86.54(16)$ & $86.60(9)$ & $86.5(1)$ & 0.53 & 89.0 & 2.54 \\
\hline $\mathrm{C}(2)-\mathrm{Rh}(1)-\mathrm{O}(3)$ & $89.52(8)$ & $89.57(7)$ & $89.72(6)$ & $89.33(13)$ & $89.66(7)$ & $89.75(8)$ & 0.42 & 94.3 & 4.98 \\
\hline $\mathrm{C}(1)-\mathrm{Rh}(1)-\mathrm{N}(1)$ & $93.06(8)$ & $92.67(7)$ & $92.67(6)$ & $93.72(13)$ & $93.26(8)$ & $93.13(9)$ & 1.05 & 89.4 & 4.28 \\
\hline $\mathrm{O}(3)-\mathrm{Rh}(1)-\mathrm{N}(1)$ & $90.62(6)$ & $90.72(6)$ & $90.63(5)$ & $90.41(10)$ & $90.47(6)$ & $90.55(6)$ & 0.31 & 89.4 & 1.28 \\
\hline N(1)-C(5)-C(4) & $123.07(19)$ & $123.76(18)$ & $123.68(14)$ & $123.8(3)$ & $124.38(18)$ & $123.9(2)$ & 1.31 & 124.6 & 1.51 \\
\hline$C(3)-C(4)-C(5)$ & 128.09(19) & $127.50(18)$ & $127.42(14)$ & $128.3(3)$ & 127.57(19) & $127.8(2)$ & 0.88 & 127.2 & 1.12 \\
\hline $\mathrm{O}(3)-\mathrm{C}(3)-\mathrm{C}(4)$ & 126.38(19) & $126.33(18)$ & $126.37(14)$ & $125.4(3)$ & $125.66(18)$ & $125.7(2)$ & 0.98 & 125.8 & 0.60 \\
\hline $\mathrm{Rh} \cdots \cdots \cdot \mathrm{Rh}$ & $3.5560(3)$ & $3.4816(3)$ & $3.4577(3)$ & $\begin{array}{l}3.4204(5) \\
3.4945(5)\end{array}$ & $\begin{array}{l}3.3272(5) \\
3.4425(5)\end{array}$ & $\begin{array}{l}3.3085(2) \\
3.4358(2)\end{array}$ & & 1.855 & \\
\hline
\end{tabular}




\subsubsection{Structure}

The crystal data and structure refinement of the two $\left[\mathrm{Rh}\left(\mathrm{CH}_{3} \mathrm{COCHCN}(\mathrm{Ph}) \mathrm{CH}_{3}\right)(\mathrm{CO})_{2}\right]$ crystals of this study are summarised in Table 1, while Table 2 compares selected geometrical data of the two crystals from this study (obtained for both the $\alpha$ - and $\beta$-polymorphs, from data collections at different temperatures) to the corresponding data of a previously published $\beta$-polymorph, collected at $100 \mathrm{~K}$ [13]. A molecular diagram of the $\alpha$-polymorph at $150 \mathrm{~K}$, showing the atom labelling used for all six structures, is illustrated in Figure 2.

The $\alpha$-polymorph of $\left[\mathrm{Rh}\left(\mathrm{CH}_{3} \mathrm{COCHCN}(\mathrm{Ph}) \mathrm{CH}_{3}\right)(\mathrm{CO})_{2}\right]$ crystallised in the $\mathrm{P} 2 / 1 \mathrm{n}$ space group, with four molecules per unit cell. The four bond angles around the rhodium atom deviate slightly $\left(<3^{\circ}\right)$ from the normally expected $90^{\circ}$ bond angle for a square planar complex, as can be seen from the bond angles of the $\alpha$-polymorph at $150 \mathrm{~K}$ (see Table 2 , second column of the $\alpha$-polymorphs): namely, bond angle $\mathrm{C}(1)-\mathrm{Rh}(1)-\mathrm{C}(2)$ of $87.03(9)^{\circ}$, bond angle $\mathrm{C}(2)-\mathrm{Rh}(1)-\mathrm{O}(3)$ of $89.57(7)^{\circ}$, bond angle $\mathrm{C}(1)-\mathrm{Rh}(1)-\mathrm{N}(1)$ of $92.67(7)^{\circ}$ and bond angle $\mathrm{O}(3)-\mathrm{Rh}(1)-\mathrm{N}(1)$ of $90.72(6)^{\circ}$. The atoms around rhodium $(\mathrm{N} 1, \mathrm{O} 3, \mathrm{C} 1$ and $\mathrm{C} 2)$ as well as rhodium itself all lie in the same plane, with $\mathrm{C} 1$ having the maximum deviation from this plane of 0.031(2) $\AA$. Similarly, the atoms of the backbone of the bidentate ligand (O3, C3, C4, C5 and N1) as well as $\mathrm{Rh}$ itself, all lie in another plane (slanted at $0.49^{\circ}$ with respect to the plane through $\mathrm{Rh}, \mathrm{N} 1, \mathrm{O} 3, \mathrm{C} 1$ and $\mathrm{C} 2$ ), with $\mathrm{O} 3$ having the maximum deviation from that plane of 0.021(1) $\AA$. The angle between the latter plane and the plane through the phenyl ring is $81.70^{\circ}$. The separate molecules form dimers, which are packed about a centre of symmetry.

The $\beta$-polymorph of $\left[\mathrm{Rh}\left(\mathrm{CH}_{3} \mathrm{COCHCN}(\mathrm{Ph}) \mathrm{CH}_{3}\right)(\mathrm{CO})_{2}\right]$ crystallised in the $\mathrm{I}$ /a space group, with eight molecules per unit cell. The structure of the $\beta$-polymorph is very similar to that of the $\alpha$ polymorph of $\left[\mathrm{Rh}\left(\mathrm{CH}_{3} \mathrm{COCHCN}(\mathrm{Ph}) \mathrm{CH}_{3}\right)(\mathrm{CO})_{2}\right]$, as can be seen from the structure overlay of the two polymorphs, as illustrated in Figure 3 (top left). 


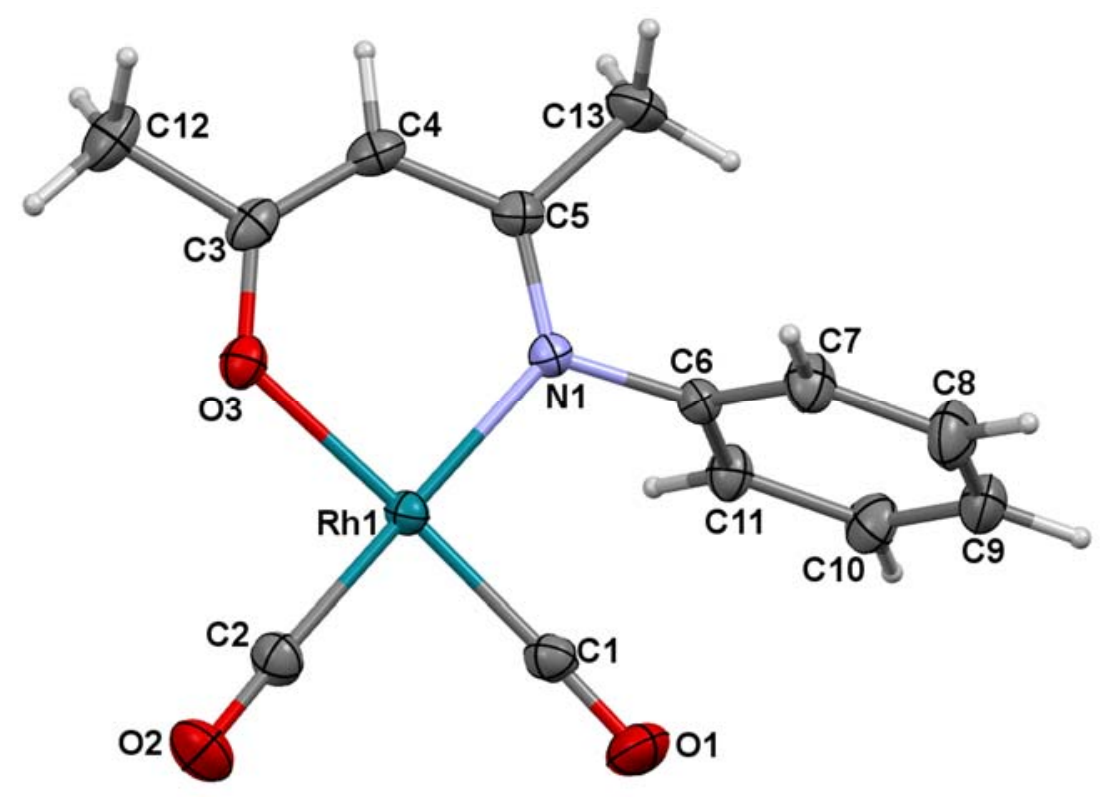

Figure 2: A perspective drawing of the molecular structure of $\left[\mathrm{Rh}\left(\mathrm{CH}_{3} \mathrm{COCHCN}(\mathrm{Ph}) \mathrm{CH}_{3}\right)(\mathrm{CO})_{2}\right]$ (the $\alpha$-polymorph at $150 \mathrm{~K}$ ), showing the atom numbering scheme. Atomic displacement parameters (ADPs) are shown at the $50 \%$ probability level.

The metal-ligand distances in transition metal complexes are important in determining the structure and reactivity of the metal complex. Therefore in Table 2 the bond lengths and bond angles around the rhodium atom, as well as selected geometrical parameters involving the backbone of the bidentate ligand of the $\alpha$ - and $\beta$-polymorph obtained crystallographically in this study, are compared to each other and also to the corresponding parameters of the previously published structure of the $\beta$-polymorph, collected at $100 \mathrm{~K} \quad[13]$, of complex $\left[\mathrm{Rh}\left(\mathrm{CH}_{3} \mathrm{COCHCN}(\mathrm{Ph}) \mathrm{CH}_{3}\right)(\mathrm{CO})_{2}\right]$. The maximum difference between the selected bond lengths and bond angles of both polymorphs obtained at different temperatures, is only $0.024 \AA$ and $1.3^{\circ}$ respectively. The main difference between the geometries of the $\alpha$ - and $\beta$-polymorphs lies in the orientation of the phenyl and methyl groups on the ligand, as is clear from the overlay of the different structures, as presented in Figure 3 (top left). However, the orientation of the phenyl and methyl groups on the ligand did not change with temperature for a specific polymorph, see Figure 3 (bottom). 


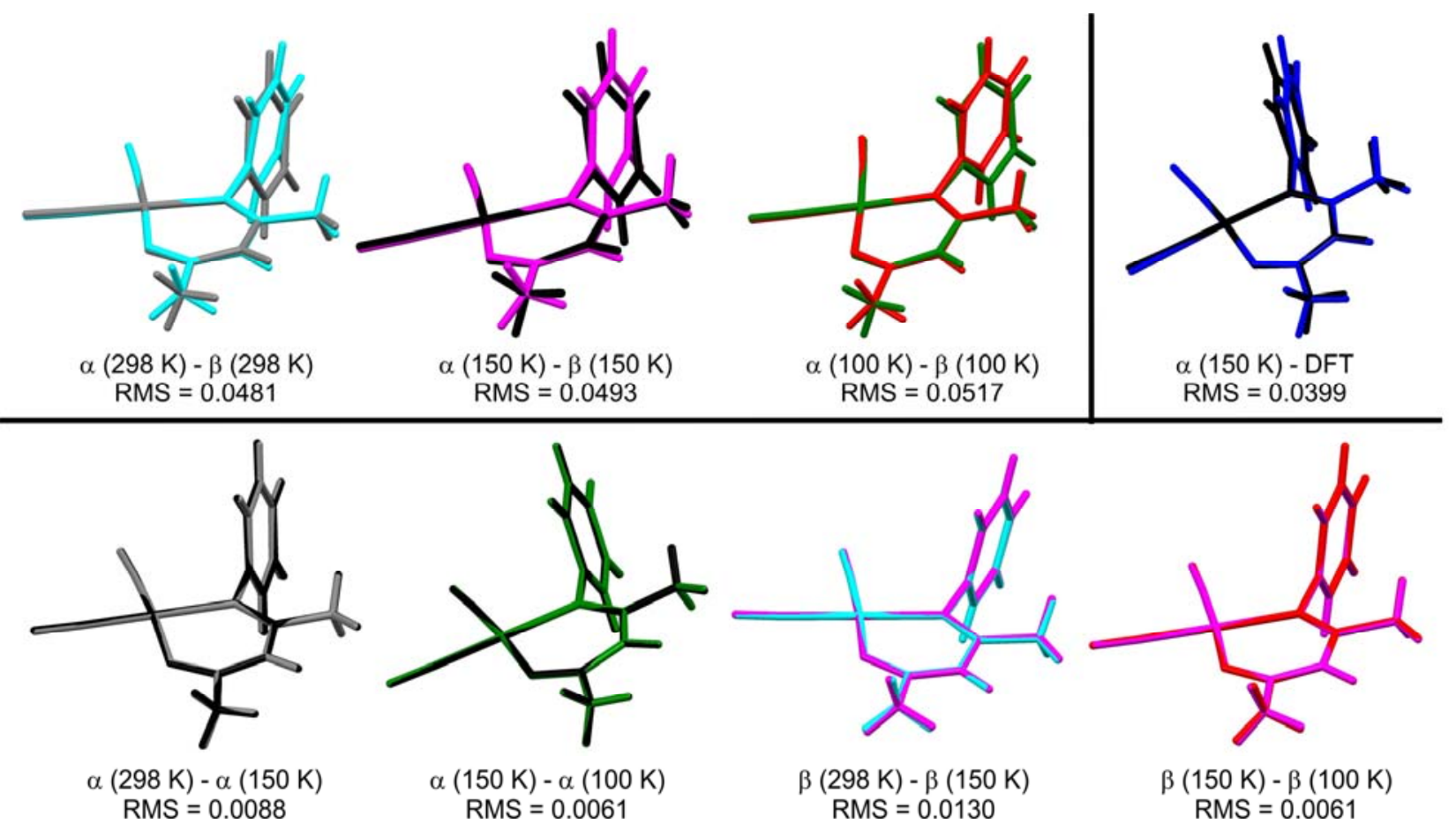

Figure 3: Overlay of the structures of the $\alpha$-polymorph (298 K, grey), $\alpha$-polymorph (150 K, black), $\alpha$-polymorph (100 K, green), $\beta$-polymorph (298 K, cyan), $\beta$-polymorph (150 K, magenta) from this study and $\beta$-polymorph $(100 \mathrm{~K}$, red) from a previous study [13], of $\left[\mathrm{Rh}\left(\mathrm{CH}_{3} \mathrm{COCHCN}(\mathrm{Ph}) \mathrm{CH}_{3}\right)(\mathrm{CO})_{2}\right]$ with each other. The root means square (RMS) overlay values, when using the $\mathrm{Rh}$ atom, the atoms of the backbone of the bidentate ligand, as well as the carbons of the two carbonyl groups of each structure in the overlay, are indicated. Also shown (top right) is the overlay of the experimentally obtained structure of the $\alpha$-polymorph $(150 \mathrm{~K}$, black) of $\left[\mathrm{Rh}\left(\mathrm{CH}_{3} \mathrm{COCHCN}(\mathrm{Ph}) \mathrm{CH}_{3}\right)(\mathrm{CO})_{2}\right]$ with the theoretical mono nuclear DFT optimised molecule (blue).

\subsubsection{Packing}

In Figure 4, packing diagrams are compared of two crystals in this study, namely of the $\alpha$ polymorph (collected at $150 \mathrm{~K}$, with space group $\mathrm{P} 22_{1} / \mathrm{n}$ ) and the $\beta$-polymorph (collected at $150 \mathrm{~K}$, with space group I2/a). Crystals of both polymorphs $(\alpha$ and $\beta)$ form dinuclear $\left[\mathrm{Rh}\left(\mathrm{CH}_{3} \mathrm{COCHCN}(\mathrm{Ph}) \mathrm{CH}_{3}\right)(\mathrm{CO})_{2}\right]_{2}$ units in the solid state, with differing inter-molecular rhodiumrhodium distances which decrease slightly upon temperature lowering, namely decreasing from $3.5560(3)(298 \mathrm{~K})$ to $3.4816(3)(150 \mathrm{~K})$ to $3.4577(3)(100 \mathrm{~K})$ for the $\alpha$-polymorph; and decreasing from $3.4204(5)(298 \mathrm{~K})$ to $3.3272(5)(150 \mathrm{~K})$ to $3.3085(2)(100 \mathrm{~K})$ for the $\beta$-polymorph (values given in $\AA$, Table 2). This rhodium-rhodium distance is larger in a dinuclear unit of the $\alpha$ polymorph at the lowest temperature of $100 \mathrm{~K}$, than in a dimer of the $\beta$-polymorph at room 
temperature $(298 \mathrm{~K})$. Consequently, the dinuclear $\left[\mathrm{Rh}\left(\mathrm{CH}_{3} \mathrm{COCHCN}(\mathrm{Ph}) \mathrm{CH}_{3}\right)(\mathrm{CO})_{2}\right]_{2}$ units of the $\beta$-polymorphs with shorter inter-molecular rhodium-rhodium distances, rather form extended linear chains of metal atoms along the a-axis, regardless of temperature; while packing in the solid state of the $\alpha$-polymorph does not form any linear chains of rhodium atoms, but only pack in pairs of dinuclear $\left[\mathrm{Rh}\left(\mathrm{CH}_{3} \mathrm{COCHCN}(\mathrm{Ph}) \mathrm{CH}_{3}\right)(\mathrm{CO})_{2}\right]_{2}$ units. In the case of the $\alpha$-polymorph, the formation of linear wire-like chains of inter-molecular rhodium-rhodium atoms is further impeded, due to the larger lateral shift (of ca. $0.9 \AA$ ) between the two separate molecules in each dinuclear $\left[\mathrm{Rh}\left(\mathrm{CH}_{3} \mathrm{COCHCN}(\mathrm{Ph}) \mathrm{CH}_{3}\right)(\mathrm{CO})_{2}\right]_{2}$ unit, relative to a smaller lateral shift of only ca. $0.3-0.4 \AA$ between the molecules of the $\beta$-polymorph dimer. The difference in crystal packing of the $\alpha$ and $\beta$ dimers show that these are therefore packing polymorphs, since dinuclear $\left[\mathrm{Rh}\left(\mathrm{CH}_{3} \mathrm{COCHCN}(\mathrm{Ph}) \mathrm{CH}_{3}\right)(\mathrm{CO})_{2}\right]_{2}$ can exist in more than one crystalline state. Packing polymorphism is a result of differences in crystal packing for the same molecule, also leading to differences in the space group and the cell dimensions of the different polymorphs.

The molecular pair-wise packing observed for the $\alpha$-polymorph $(150 \mathrm{~K})$ is further stabilised by parallel ring1...ring1 interaction (ring1 defined by Rh1,O3, C3, C4, C5, N1) at a distance of 4.465(1) $\AA$, as well as ring1...ring2 interaction (ring2 defined by C6, C7, C8, C9, C10, C11) at a distance of 4.607(1) $\AA$ between adjacent molecules in each dimeric unit. Some additional interaction of the type X-Y...ring-centroid (perpendicular) was observed: for C9-H9...ring1 the distance is $2.79 \AA$ and for $\mathrm{C} 1-\mathrm{O} 1$...ring 2 the distance is $3.47 \AA$.

From the differences found in the solid state packing of all six crystal structures we can therefore conclude that the interaction of the rhodium atoms between two adjacent $\left[\mathrm{Rh}\left(\mathrm{CH}_{3} \mathrm{COCHCN}(\mathrm{Ph}) \mathrm{CH}_{3}\right)(\mathrm{CO})_{2}\right]$ molecules can lead to either crystallising as extended linear chains of metal atoms ( $\beta$-polymorph), or otherwise under differing crystallising conditions (such as solvent and temperature), they do not form infinite metal-metal chains, but crystallise as dinuclear units in the solid state ( $\alpha$-polymorph) instead. It has previously been found that the solid state packing of other related $\left[\mathrm{M}(\beta\right.$-diketonato $\left.)(\mathrm{CO})_{2}\right]$ complexes either displayed extended linear chains of metal atoms $[8,9,10,32,33,34,35]$ in some instances, or otherwise they instead formed dinuclear $\left[\mathrm{M}(\beta \text {-diketonato })(\mathrm{CO})_{2}\right]_{2}$ units for other complexes [5,6,7]. However, to our knowledge, no case of polymorphism has as yet been reported for these related $\left[\mathrm{M}\left(\beta\right.\right.$-diketonato $\left.(\mathrm{CO})_{2}\right]$ complexes, as was found in this study for complex $\left[\mathrm{Rh}\left(\mathrm{CH}_{3} \mathrm{COCHCN}(\mathrm{Ph}) \mathrm{CH}_{3}\right)(\mathrm{CO})_{2}\right]$. 
(a)

(b)
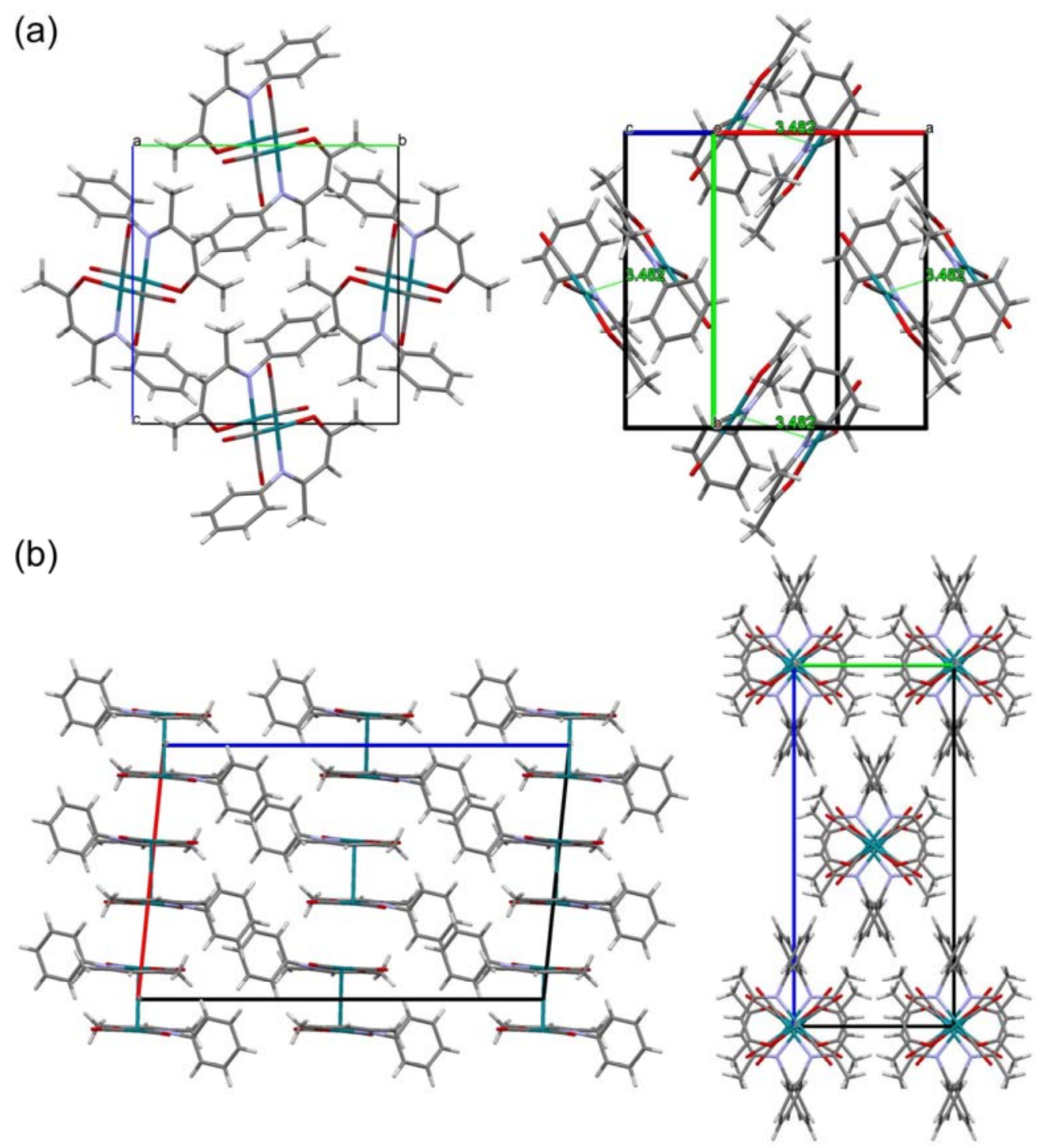

Figure 4: Packing diagrams of $\left[\mathrm{Rh}\left(\mathrm{CH}_{3} \mathrm{COCHCN}(\mathrm{Ph}) \mathrm{CH}_{3}\right)(\mathrm{CO})_{2}\right]$ of (a) the $\alpha$-polymorph $(150 \mathrm{~K}$, space group $\mathrm{P} 21 / \mathrm{n}$ ) along the a (top left) and $\mathrm{c}^{*}$ (top right) axis, and of (b) the $\beta$-polymorph (150 K, space group I2/a) along the $\mathrm{b}$ (bottom left) and a (bottom right) axis.

\subsection{Computational chemistry}

\subsubsection{Structure of mono nuclear $\left[\mathrm{Rh}\left(\mathrm{CH}_{3} \mathrm{COCHCN}(\mathrm{Ph}) \mathrm{CH}_{3}\right)(\mathrm{CO})_{2}\right]$}

The overlay of the theoretical DFT optimised single molecular unit of $\left[\mathrm{Rh}\left(\mathrm{CH}_{3} \mathrm{COCHCN}(\mathrm{Ph}) \mathrm{CH}_{3}\right)(\mathrm{CO})_{2}\right]$, onto the coordinates of the experimentally obtained solid state data of the $\alpha$-polymorph $(150 \mathrm{~K})$ of this study, is presented in Figure 3 (top right). The maximum difference between the bond lengths and bond angles around rhodium of any experimental structure and the theoretical DFT optimised bond lengths and bond angles around rhodium, is $0.042 \AA$ and $4.98^{\circ}$ respectively (See Table 2 last column). This is comparable with the maximum difference between the selected bond lengths and bond angles of all six crystal structures obtained at different 
temperatures for both polymorphs reported in this study, namely $0.024 \AA$ and $1.3^{\circ}$ respectively (see Table 2, column 8). The slightly overestimated DFT calculated metal-ligand bond lengths are generally observed for gas phase optimisations [36], and therefore considered insignificant. Similar slightly overestimated rhodium-ligand bond lengths for gas phase optimisations, relative to experimentally obtained solid state crystal data, have previously been obtained for related rhodium$\beta$-diketonato complexes [37,38,39].

\subsubsection{Structure of the $\left[\mathrm{Rh}\left(\mathrm{CH}_{3} \mathrm{COCHCN}(\mathrm{Ph}) \mathrm{CH}_{3}\right)(\mathrm{CO})_{2}\right]_{2}$ dimer}

Both the $\alpha$ - and $\beta$-polymorphs of $\left[\mathrm{Rh}\left(\mathrm{CH}_{3} \mathrm{COCHCN}(\mathrm{Ph}) \mathrm{CH}_{3}\right)(\mathrm{CO})_{2}\right]$ thus pack in dimeric units in the solid state. An understanding on a molecular level of the rhodium-rhodium and other intermolecular interactions between the two separate $\left[\mathrm{Rh}\left(\mathrm{CH}_{3} \mathrm{COCHCN}(\mathrm{Ph}) \mathrm{CH}_{3}\right)(\mathrm{CO})_{2}\right]$ molecules in the dinuclear unit is presented here. In this section the computational chemistry results, calculated on the coordinates of four models of the $\left[\mathrm{Rh}\left(\mathrm{CH}_{3} \mathrm{COCHCN}(\mathrm{Ph}) \mathrm{CH}_{3}\right)(\mathrm{CO})_{2}\right]_{2}$ dimeric unit, are described. The four theoretical models will be referred to hereafter as the DFT optimised dimer 1, DFT single point 2, DFT single point 3 and DFT single point 4 respectively. The first model, DFT optimised dimer 1 , is the gas phase optimised dinuclear $\left[\mathrm{Rh}\left(\mathrm{CH}_{3} \mathrm{COCHCN}(\mathrm{Ph}) \mathrm{CH}_{3}\right)(\mathrm{CO})_{2}\right]_{2}$ structure, based on the theoretical coordinates obtained by DFT calculations for a dimeric molecular unit in this study. The second, third and fourth models, involve single point calculations based on crystallographically obtained coordinates, obtained in this and a previous study [13] for dimer $\left[\mathrm{Rh}\left(\mathrm{CH}_{3} \mathrm{COCHCN}(\mathrm{Ph}) \mathrm{CH}_{3}\right)(\mathrm{CO})_{2}\right]_{2}$, and were chosen so that the lateral shift between adjacent rhodium atoms in the dimeric unit decreases consistently, in going from the first model (DFT optimised dimer 1, lateral shift $=1.590 \AA)$ to the fourth model (DFT single point 4, lateral shift = $0 \AA$ ), where in the latter case, the two rhodium atoms of adjacent molecular units are aligned directly "on top of each other" (with inclination angle $\alpha=90^{\circ}$, see Figure 5), as shown in Figure 6. The second model (DFT single point 2) was calculated, based on the coordinates of the solid state crystal structure data of dimeric unit of the $\alpha$-polymorph (at $150 \mathrm{~K}$, with the exact experimental lateral shift of $0.925 \AA$ between adjacent rhodium atoms), while the third model (DFT single point 3) was based on the coordinates of the dimeric unit of the $\beta$-polymorph (at $100 \mathrm{~K}$, from a previous study [13], with the exact experimental lateral shift of $0.310 \AA$ between adjacent rhodium atoms). The fourth model (DFT single point 4) was conducted on the coordinates of the same previously published $\beta$-polymorph crystal structure (at $100 \mathrm{~K}$, as used for DFT single point 3), however with the two molecular units being aligned directly above each other, with the rhodium-rhodium axis near perpendicular to the square plane through the molecules, i.e. with the lateral shift between the two separate molecular units reduced to near $0 \AA$ (inclination $\alpha=90^{\circ}$, see Figure 5). The DFT 
calculated electronic energies of DFT single point 2 ( $\alpha$-polymorph at $150 \mathrm{~K}$ with lateral shift $=$ $0.925 \AA$ ), DFT single point 3 ( $\beta$-polymorph at $100 \mathrm{~K}$ with lateral shift $=0.310 \AA$ ) and DFT single point 4 (with no lateral shift) are very close to each other (namely $8.42 \mathrm{eV} \approx 8.28 \mathrm{eV} \approx 8.30 \mathrm{eV}$ respectively), but all of them are ca. $8.3 \mathrm{eV}$ higher than the DFT optimised dimer 1, see Table 3. The interactions between the two separate mono nuclear units $\left[\mathrm{Rh}\left(\mathrm{CH}_{3} \mathrm{COCHCN}(\mathrm{Ph}) \mathrm{CH}_{3}\right)(\mathrm{CO})_{2}\right]$ in each model, can collectively be described by the rhodium-rhodium distances, the interplanar separation between the two units, the lateral shift between the two individual units, as well as the inclination angle $\alpha$, between the Rh-Rh vector and the plane through one molecular unit, as defined in Figure 5 [4] and as summarised in Table 3. The four models are visualised in Figure 6, indicating the lateral shift between adjacent rhodium atoms in red. It is clear that the lateral shift decreases in going from the DFT optimised dimer $1(1.590 \AA)$ to DFT single point $2(0.925 \AA)$ to DFT single point $3(0.310 \AA)$ to DFT single point $4(0 \AA)$, where in the latter, the two rhodium atoms of adjacent molecular units are aligned directly "on top of each other" (inclination angle $\alpha=$ $90^{\circ}$, see Figure 5). It is expected that in the parallel aligned dimers of DFT single point 4, wirelike linear metal-metal stacking of the $\left[\mathrm{Rh}\left(\mathrm{CH}_{3} \mathrm{COCHCN}(\mathrm{Ph}) \mathrm{CH}_{3}\right)(\mathrm{CO})_{2}\right]_{2}$ units will be favoured, as has also been observed in the three experimental crystal structures of the $\beta$-polymorph of $\left[\mathrm{Rh}\left(\mathrm{CH}_{3} \mathrm{COCHCN}(\mathrm{Ph}) \mathrm{CH}_{3}\right)(\mathrm{CO})_{2}\right]_{2}$ (listed in Table 2), as well as in the solid state structure of a related complex from literature, namely [Rh(acetylacetono)(CO)2] [12].

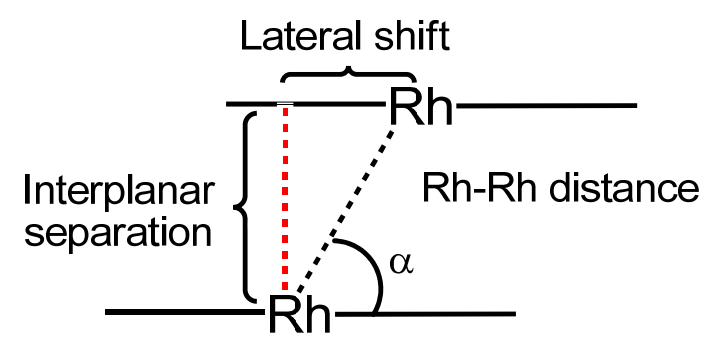

Figure 5: Description of inter-molecular distances between two adjacent molecular units of the dimer $\left[\mathrm{Rh}\left(\mathrm{CH}_{3} \mathrm{COCHCN}(\mathrm{Ph}) \mathrm{CH}_{3}\right)(\mathrm{CO})_{2}\right]_{2}$. The plane through each of the two molecules is defined by Rh1-O3-N1-C2-C1.

Table 3: DFT calculated energies and inter-molecular distances for four different $\left[\mathrm{Rh}\left(\mathrm{CH}_{3} \mathrm{COCHCN}(\mathrm{Ph}) \mathrm{CH}_{3}\right)(\mathrm{CO})_{2}\right]_{2}$ dimer models, with the latter three models based on coordinates obtained from crystallographic data, while the first model is based on theoretically calculated coordinates for a dimeric molecular unit of the complex. 


\begin{tabular}{|c|c|c|c|c|c|}
\hline Complex & $\begin{array}{l}\text { Relative } \\
\text { electronic } \\
\text { energy (eV) }\end{array}$ & $\begin{array}{l}\text { Rh-Rh } \\
\text { distance }(\AA)\end{array}$ & $\begin{array}{l}\text { Angle } \\
\alpha\left({ }^{\circ}\right)\end{array}$ & $\begin{array}{l}\text { Interplanar } \\
\text { separation }(\AA)\end{array}$ & $\begin{array}{l}\text { Lateral } \\
\text { shift }(\AA)\end{array}$ \\
\hline DFT optimised dimer 1 & 0.00 & 4.474 & 69.8 & 4.182 & 1.590 \\
\hline $\begin{array}{l}\text { DFT single point } 2 \\
(\alpha \text {-polymorph at } 150 \mathrm{~K})\end{array}$ & 8.42 & 3.482 & 73.9 & 3.357 & 0.925 \\
\hline $\begin{array}{l}\text { DFT single point } 3 \\
(\beta \text {-polymorph at } 100 \mathrm{~K})\end{array}$ & 8.28 & 3.309 & 77.6 & 3.294 & 0.310 \\
\hline $\begin{array}{l}\text { DFT single point } 4 \\
\text { (with no lateral shift) }\end{array}$ & 8.30 & 3.309 & 90.0 & 3.309 & 0.000 \\
\hline
\end{tabular}

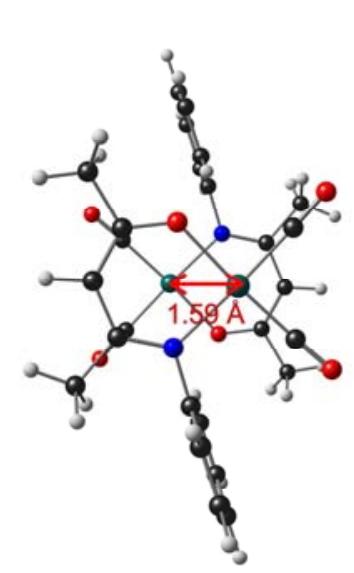

DFT optimized dimer 1

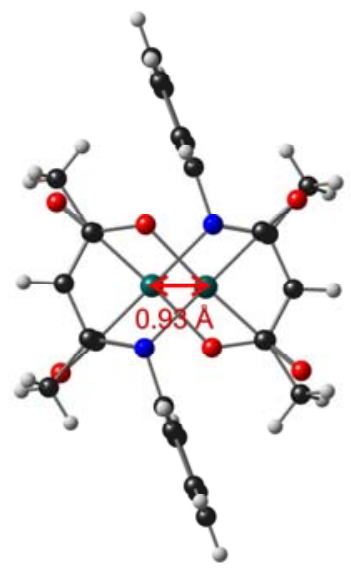

DFT single point 2

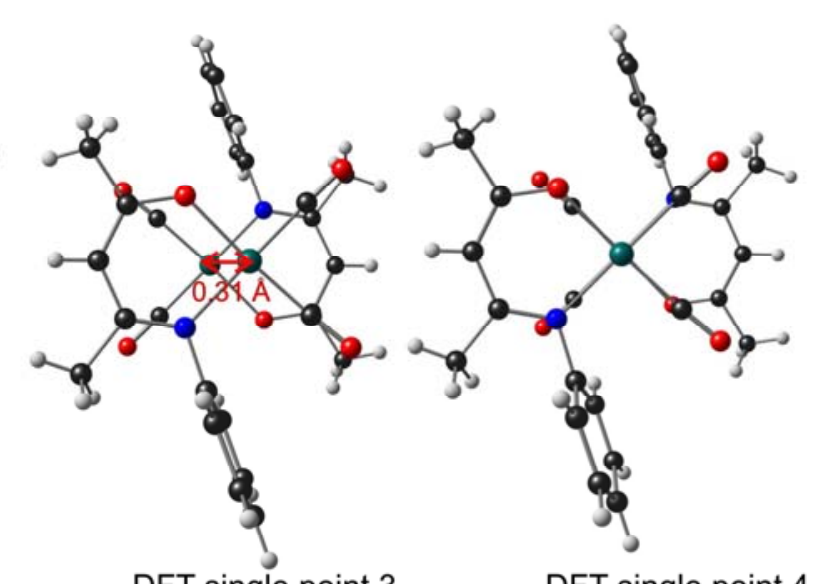

DFT single point 3

DFT single point 4

Figure 6: Visualisation of the lateral shift between two adjacent molecular units (indicated in red), in each of the four different DFT models of the dimer $\left[\mathrm{Rh}\left(\mathrm{CH}_{3} \mathrm{COCHCN}(\mathrm{Ph}) \mathrm{CH}_{3}\right)(\mathrm{CO})_{2}\right]_{2}$, namely $1.590 \AA>0.925 \AA>0.310 \AA)>0 \AA$, as seen directly from top.

\subsubsection{Molecular orbitals}

The character of the highest occupied molecular orbital (HOMO) of the DFT optimised molecule $\left[\mathrm{Rh}\left(\mathrm{CH}_{3} \mathrm{COCHCN}(\mathrm{Ph}) \mathrm{CH}_{3}\right)(\mathrm{CO})_{2}\right]$ (mono nuclear unit), is distributed over the backbone of the 2(phenylamino)pent-3-en-4-onato ligand, while the HOMO-1 is of mainly $d_{z^{2}}$ character on rhodium (Figure 7 left). The order of these two orbitals is opposite to what has previously been found for complexes $\left[\mathrm{Rh}(\beta\right.$-diketonato $\left.)(\mathrm{CO})_{2}\right][11,40]$ and $\left[\operatorname{Ir}(\right.$ acetylacetonato $\left.)(\mathrm{CO})_{2}\right][41]$, where the HOMO was of mainly $d_{z^{2}}$ character on the metal, instead of on the ligand. Interaction between these two MOs (ligand HOMO and $d_{z^{2}}$ HOMO-1) from each separate mono nuclear unit in dinuclear $\left[\mathrm{Rh}\left(\mathrm{CH}_{3} \mathrm{COCHCN}(\mathrm{Ph}) \mathrm{CH}_{3}\right)(\mathrm{CO})_{2}\right]_{2}$, leads to the top four occupied molecular orbitals of the dinuclear $\left[\mathrm{Rh}\left(\mathrm{CH}_{3} \mathrm{COCHCN}(\mathrm{Ph}) \mathrm{CH}_{3}\right)(\mathrm{CO})_{2}\right]_{2}$ pair, namely two bonding MOs (one ligand based and the other rhodium $d_{z^{2}}$ based) and two antibonding MOs (also one ligand based and the other rhodium $d_{z^{2}}$ based), see Figure 7 (right) for the top four MOs of DFT single point 2 as 
representative example. Since the $d_{z^{2}}$ MOs from each $\left[\mathrm{Rh}\left(\mathrm{CH}_{3} \mathrm{COCHCN}(\mathrm{Ph}) \mathrm{CH}_{3}\right)(\mathrm{CO})_{2}\right]$ unit are already are occupied, overlapping of these $d_{z^{2}}$ orbitals do not form a formal bond between the rhodium centres, but lead to weak intermolecular interactions between the rhodium centres from adjacent molecules. The $d_{z^{2}}$ based bonding orbitals of rhodium stabilise the interaction, or weak metallophilic bond, between the two rhodium centres of a dinuclear $\left[\mathrm{Rh}\left(\mathrm{CH}_{3} \mathrm{COCHCN}(\mathrm{Ph}) \mathrm{CH}_{3}\right)(\mathrm{CO})_{2}\right]_{2}$ unit, while the $d_{z^{2}}$ based antibonding orbitals destabilise the rhodium-rhodium bond. A balance between the bonding and antibonding intermolecular orbitals of mainly $d_{z 2}$ type, determine the strength of the weak intermolecular interactions between adjacent $\left[\mathrm{Rh}\left(\mathrm{CH}_{3} \mathrm{COCHCN}(\mathrm{Ph}) \mathrm{CH}_{3}\right)(\mathrm{CO})_{2}\right]$ molecules. The energy of the $d_{z^{2}}$ based bonding orbitals of DFT single point 3 and DFT single point 4 is more than $0.2 \mathrm{eV}$ lower (more negative i.e. more stable) than that of the DFT optimised dimer 1 and DFT single point 2 models (Figure 7), therefore contributing to the Rh-Rh wire formation observed for both DFT single point 3 and DFT single point 4 in the solid state. On the other hand, the energies of the $d_{z^{2}}$ based antibonding orbitals, increases with decrease in the lateral shift between the two separate molecular units in dinuclear $\left[\mathrm{Rh}\left(\mathrm{CH}_{3} \mathrm{COCHCN}(\mathrm{Ph}) \mathrm{CH}_{3}\right)(\mathrm{CO})_{2}\right]_{2}$, see Figure 7.

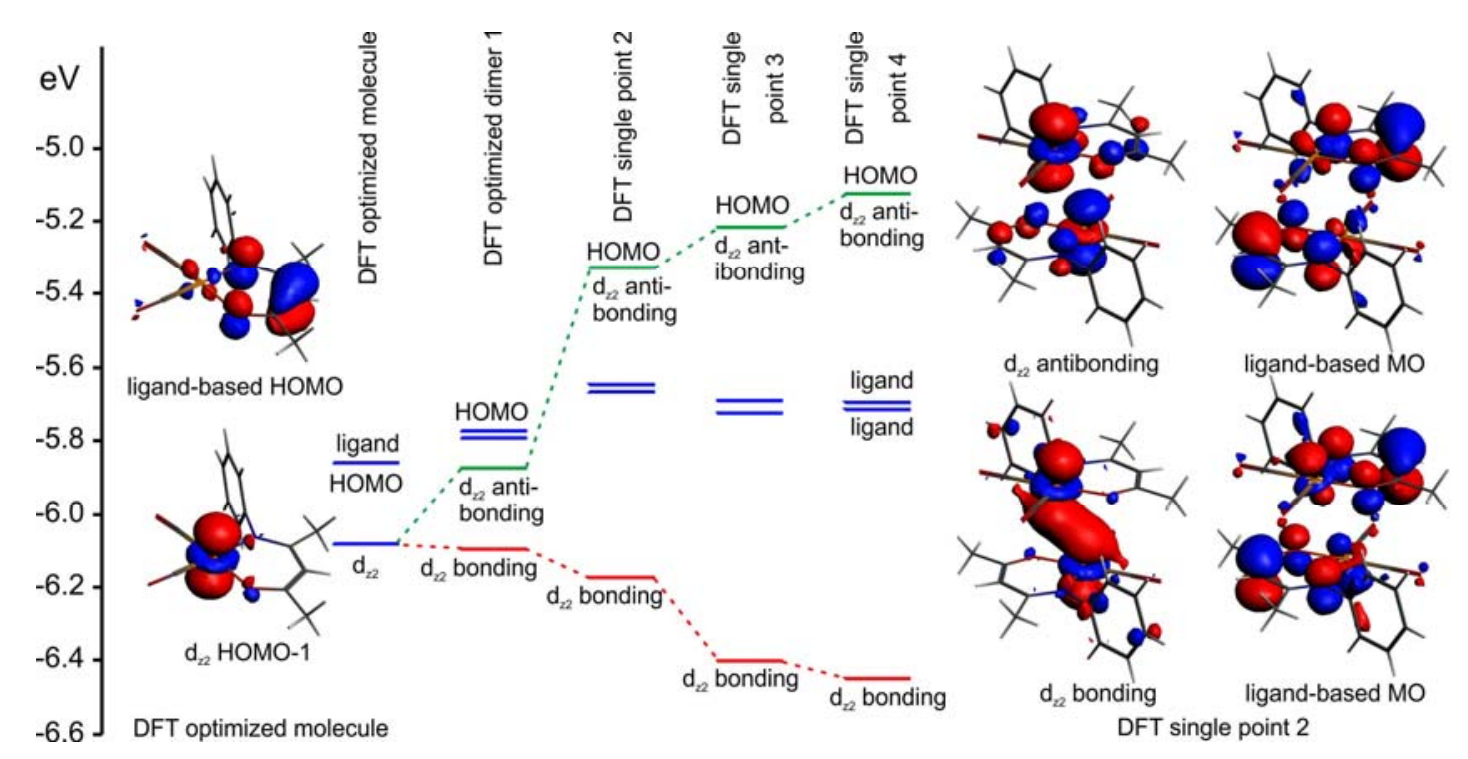

Figure 7: Visualisation of the relative energies of the top four occupied molecular orbitals of the single DFT optimised molecule $\left[\mathrm{Rh}\left(\mathrm{CH}_{3} \mathrm{COCHCN}(\mathrm{Ph}) \mathrm{CH}_{3}\right)(\mathrm{CO})_{2}\right]$ (mono nuclear unit) (left), together with the four dimolecular $\left[\mathrm{Rh}\left(\mathrm{CH}_{3} \mathrm{COCHCN}(\mathrm{Ph}) \mathrm{CH}_{3}\right)(\mathrm{CO})_{2}\right]_{2}$ models calculated in this study. Visualisation of selected MOs of DFT calculations for DFT single point 2 ( $\alpha$-polymorph at $150 \mathrm{~K}$ ), as representative of the top four MOs of the dimolecular models, are shown on the right. 


\subsubsection{Natural bond orbitals (NBO)}

The inter-molecular interactions between the two molecular units of dimeric $\left[\mathrm{Rh}\left(\mathrm{CH}_{3} \mathrm{COCHCN}(\mathrm{Ph}) \mathrm{CH}_{3}\right)(\mathrm{CO})_{2}\right]_{2}$ were evaluated by the natural bond orbitals $(\mathrm{NBO})$ analysis method of Weinhold, since an NBO analysis provides information about interactions between filled Lewis type donor NBOs (occupation numbers near 2) and empty non-Lewis acceptor NBOs (occupation numbers near 0 ). NBO types important for the inter-molecular interactions between the two single molecular units of dimeric $\left[\mathrm{Rh}\left(\mathrm{CH}_{3} \mathrm{COCHCN}(\mathrm{Ph}) \mathrm{CH}_{3}\right)(\mathrm{CO})_{2}\right]_{2}$, are the following types: the 1-centre core (CR), the 1-centre non-bonded (lone pair, LP) and the 2-centre bond (BD) NBOs $[42,43]$. Selected results obtained from the NBO analysis of the four dimeric models used in this study, are summarised in Table 4, and selected NBOs are visualised in Figure 8, while elected donor - acceptor NBO interactions between the two rhodium centres in bimolecular $\left[\mathrm{Rh}\left(\mathrm{CH}_{3} \mathrm{COCHCN}(\mathrm{Ph}) \mathrm{CH}_{3}\right)(\mathrm{CO})_{2}\right]_{2}$ are visualised in Figure 9.

In the DFT single point 3 model (based on the coordinates of the $\beta$-polymorph at $100 \mathrm{~K}$ ) where the two molecular units exhibit a large overlap (with a smaller lateral shift of $0.310 \AA$ ), the NBO calculations generally produced larger donor-acceptor interaction energies $E(2)$ between a filled (bonding or lone pair) Lewis type NBO on rhodium of the one molecular unit (which acts as a donor) and an empty (antibonding or Rydberg) non-Lewis NBO on rhodium of the other molecular unit (which acts as an acceptor), than the calculated E(2) for the DFT optimised dimer 1 (with a larger lateral shift of $1.590 \AA$ ) or DFT single point 2 (with lateral shift of $0.925 \AA$ ), see Table 4. The donor NBOs on rhodium, involved in donor-acceptor interactions, are a CR NBO of mainly $s$ character, a LP NBO of mainly $d_{z^{2}}$ character, as well as two BD NBOs, see Figure 8. The acceptor NBOs on rhodium, involved in donor-acceptor interactions, are LP* NBOs of mainly $p_{z}, p_{\mathrm{y}}$ or $p_{\mathrm{x}}$ character respectively, see Figure 8. Selected donor-acceptor interactions between the two molecular units of DFT single point 3 ( $\beta$-polymorph at $100 \mathrm{~K}$ ) are shown in Figure 9. The slightly lateral shift (of $0.310 \AA$ ) between the two units of DFT single point 3, enables interaction between the filled donor LP on Rh of mainly $d_{z^{2}}$ character and the three empty acceptor LP*s on Rh, of mainly $p_{z}, p_{\mathrm{y}}$ and $p_{\mathrm{x}}$ character respectively. This slightly lateral shift also favours donor-acceptor interactions between the $\mathrm{CR}$ on Rh of mainly $s$ character, and the two 2-centre bond NBOs, namely $\mathrm{BD}\left(\mathrm{Rh}-\mathrm{C}_{\text {trans } \mathrm{N}}\right)$ and $\mathrm{BD}\left(\mathrm{Rh}-\mathrm{C}_{\text {trans }} \mathrm{O}\right)$, with the acceptor $\mathrm{LP} *$ on Rh of mainly $p_{z}$ character. The intermolecular donor-acceptor interaction energies, $\mathrm{E}(2)$, between the two rhodium atoms of the single molecular units of dimeric $\left[\mathrm{Rh}\left(\mathrm{CH}_{3} \mathrm{COCHCN}(\mathrm{Ph}) \mathrm{CH}_{3}\right)(\mathrm{CO})_{2}\right]_{2}$, generally decrease in going from DFT single point 3 to DFT single point 2 to the DFT optimised dimer 1 gas phase model (for example $23.9 \mathrm{~kJ} \cdot \mathrm{mol}^{-1}>11.4 \mathrm{~kJ} \cdot \mathrm{mol}^{-1}>0.7 \mathrm{~kJ} \cdot \mathrm{mol}^{-1}$, for the $\mathrm{LP}\left(\mathrm{Rh}\right.$ mainly $\left.d_{z^{2}}\right)$ donor $\rightarrow \mathrm{LP} *(\mathrm{Rh}$ mainly $p_{z}$ ) acceptor interaction, also see Table 4 for the other indications), as the lateral shift 
between the two single molecular units increases (namely $0.310 \AA<0.925 \AA<1.590 \AA$ ). Similarly, for DFT single point 4, where the lateral shift approaches $0 \AA$, the interaction energies $\mathrm{E}(2)$ of the donor-acceptor interactions involving the acceptor LP*(Rh of mainly $p_{z}$ character), generally increases relative to the other three models who have a larger lateral shift between the two separate molecules (for example $30.4 \mathrm{~kJ} \cdot \mathrm{mol}^{-1}>23.9 \mathrm{~kJ} \cdot \mathrm{mol}^{-1}>11.4 \mathrm{~kJ} \cdot \mathrm{mol}^{-1}>0.7 \mathrm{~kJ} \cdot \mathrm{mol}^{-1}$, for the $\mathrm{LP}\left(\mathrm{Rh}\right.$ mainly $\left.d_{z^{2}}\right)$ donor $\rightarrow \mathrm{LP} *\left(\mathrm{Rh}\right.$ mainly $\left.p_{z}\right)$ acceptor interaction of DFT models 4, 3, 2 and 1 respectively, also see Table 4 for the other indications). However, as is also expected for a ca. 0 $\AA$ lateral shift, the donor-acceptor interactions involving the acceptors $\mathrm{LP} *\left(\mathrm{Rh}\right.$ of mainly $p_{x}$ character) and LP* (Rh of mainly $p_{y}$ character), both decrease dramatically relative to $\mathrm{E}(2)$ for DFT single point 3 and DFT single point 2 . $\mathrm{E}(2)$ of $\mathrm{LP}\left(\mathrm{Rh}\right.$ mainly $\left.d_{z^{2}}\right)$ donor $\rightarrow \mathrm{LP} *\left(\mathrm{Rh}\right.$ mainly $\left.p_{x}\right)$ acceptor decreases from $8.5 \mathrm{eV}$ to $3.5 \mathrm{eV}$, while $\mathrm{E}(2)$ of $\mathrm{LP}\left(\mathrm{Rh}\right.$ mainly $\left.d_{z^{2}}\right)$ donor $\rightarrow \mathrm{LP} *(\mathrm{Rh}$ mainly $p_{y}$ ) acceptor decreases from $6.6 \mathrm{eV}$ to $2.5 \mathrm{eV}$ (when going from DFT single point 3 to DFT single point 4) see Table 4.

In summary, these identified donor-acceptor interactions thus support the experimental observation that the $\left[\mathrm{Rh}\left(\mathrm{CH}_{3} \mathrm{COCHCN}(\mathrm{Ph}) \mathrm{CH}_{3}\right)(\mathrm{CO})_{2}\right]$ molecules are packed in pairs in the solid state, either as separate dinuclear $\left[\mathrm{Rh}(\beta \text {-diketonato })(\mathrm{CO})_{2}\right]_{2}$ dimeric units or in dinuclear units that form extended linear wire-like chains of rhodium, as was indeed found for the $\alpha$ - and $\beta$-polymorphs of this study.

Table 4: Selected second order perturbation theory donor-acceptor interaction energies, E(2) in $\mathrm{kJ} \cdot \mathrm{mol}^{-1}$, with the calculated natural bond orbital (NBO) occupations, for each of the four different theoretically calculated DFT models of the dimer $\left[\mathrm{Rh}\left(\mathrm{CH}_{3} \mathrm{COCHCN}(\mathrm{Ph}) \mathrm{CH}_{3}\right)(\mathrm{CO})_{2}\right]_{2}$, with lateral shift between adjacent molecules decreasing from model 1 to model 4 .

\begin{tabular}{|c|c|c|c|c|}
\hline Complex & $\begin{array}{l}\text { DFT } \\
\text { optimised } \\
\text { dimer } 1\end{array}$ & $\begin{array}{l}\text { DFT single } \\
\text { point } 2 \\
\text { (coordinates } \\
\text { of } \alpha \\
\text { polymorph } \\
\text { at } 150 \mathrm{~K} \text { ) }\end{array}$ & $\begin{array}{l}\text { DFT single } \\
\text { point } 3 \\
\text { (coordinates } \\
\text { of } \beta \\
\text { polymorph } \\
\text { at } 100 \mathrm{~K} \text { ) }\end{array}$ & $\begin{array}{l}\text { DFT single } \\
\text { point } 4 \\
\text { (no lateral } \\
\text { shift) }\end{array}$ \\
\hline \multicolumn{5}{|l|}{$\mathrm{E}(2) / \mathrm{kJ}^{\prime} \mathrm{mol}^{-1}$} \\
\hline $\mathrm{LP}\left(\mathrm{Rh}\right.$ mainly $\left.d_{z^{2}}\right) \rightarrow \mathrm{LP} *\left(\mathrm{Rh}\right.$ mainly $\left.p_{z}\right)$ & 0.7 & 11.4 & 23.9 & 30.5 \\
\hline $\operatorname{LP}\left(\operatorname{Rh}\right.$ mainly $\left.d_{z^{2}}\right) \rightarrow \operatorname{LP} *\left(\mathrm{Rh}\right.$ mainly $\left.p_{x}\right)$ & 0.8 & 4.8 & 8.5 & 3.5 \\
\hline $\mathrm{LP}\left(\mathrm{Rh}\right.$ mainly $\left.d_{z^{2}}\right) \rightarrow \mathrm{LP} *\left(\mathrm{Rh}\right.$ mainly $\left.p_{y}\right)$ & 0.2 & 9.7 & 6.6 & 2.5 \\
\hline $\mathrm{BD}\left(\mathrm{Rh}-\mathrm{C}_{\text {trans }} \mathrm{N}\right) \rightarrow \mathrm{LP} *\left(\mathrm{Rh}\right.$ mainly $\left.p_{z}\right)$ & 0.3 & 15.6 & 15.6 & 22.9 \\
\hline $\mathrm{BD}\left(\mathrm{Rh}-\mathrm{C}_{\text {trans } \mathrm{O}}\right) \rightarrow \mathrm{LP} *\left(\mathrm{Rh}\right.$ mainly $\left.p_{z}\right)$ & 0.3 & 7.7 & 15.4 & 22.8 \\
\hline $\mathrm{CR}(\mathrm{Rh}$ mainly $\mathrm{s}) \rightarrow \mathrm{LP} *\left(\mathrm{Rh}\right.$ mainly $\left.p_{z}\right)$ & 0.1 & 8.1 & 15.2 & 13.8 \\
\hline \multicolumn{5}{|l|}{ Occupancy } \\
\hline $\mathrm{LP}\left(\mathrm{Rh}\right.$ mainly $\left.d_{z^{2}}\right) / \mathrm{e}^{-}$ & 1.972 & 1.963 & 1.957 & 1.955 \\
\hline $\mathrm{CR}\left(\mathrm{Rh}\right.$ mainly s) / $\mathrm{e}^{-}$ & 1.989 & 1.989 & 1.988 & 1.988 \\
\hline
\end{tabular}




\begin{tabular}{lllll}
\hline $\mathrm{LP}^{*}\left(\right.$ Rh mainly $\left.p_{z}\right) / \mathrm{e}^{-}$ & 0.061 & 0.078 & 0.088 & 0.090 \\
$\mathrm{LP} *\left(\mathrm{Rh}\right.$ mainly $\left.p_{x}\right) / \mathrm{e}^{-}$ & 0.182 & 0.183 & 0.184 & 0.188 \\
$\mathrm{LP}\left(\mathrm{Rh}\right.$ mainly $\left.p_{y}\right) / \mathrm{e}^{-}$ & 0.166 & 0.168 & 0.167 & 0.171 \\
$\mathrm{BD}\left(\mathrm{Rh} \mathrm{C}_{\text {trans N })} / \mathrm{e}^{-}\right.$ & 1.960 & 1.955 & 1.951 & 1.949 \\
$\mathrm{BD}\left(\mathrm{Rh}-\mathrm{C}_{\text {trans }}\right) / \mathrm{e}^{-}$ & 1.960 & 1.953 & 1.949 & 1.948 \\
\hline
\end{tabular}

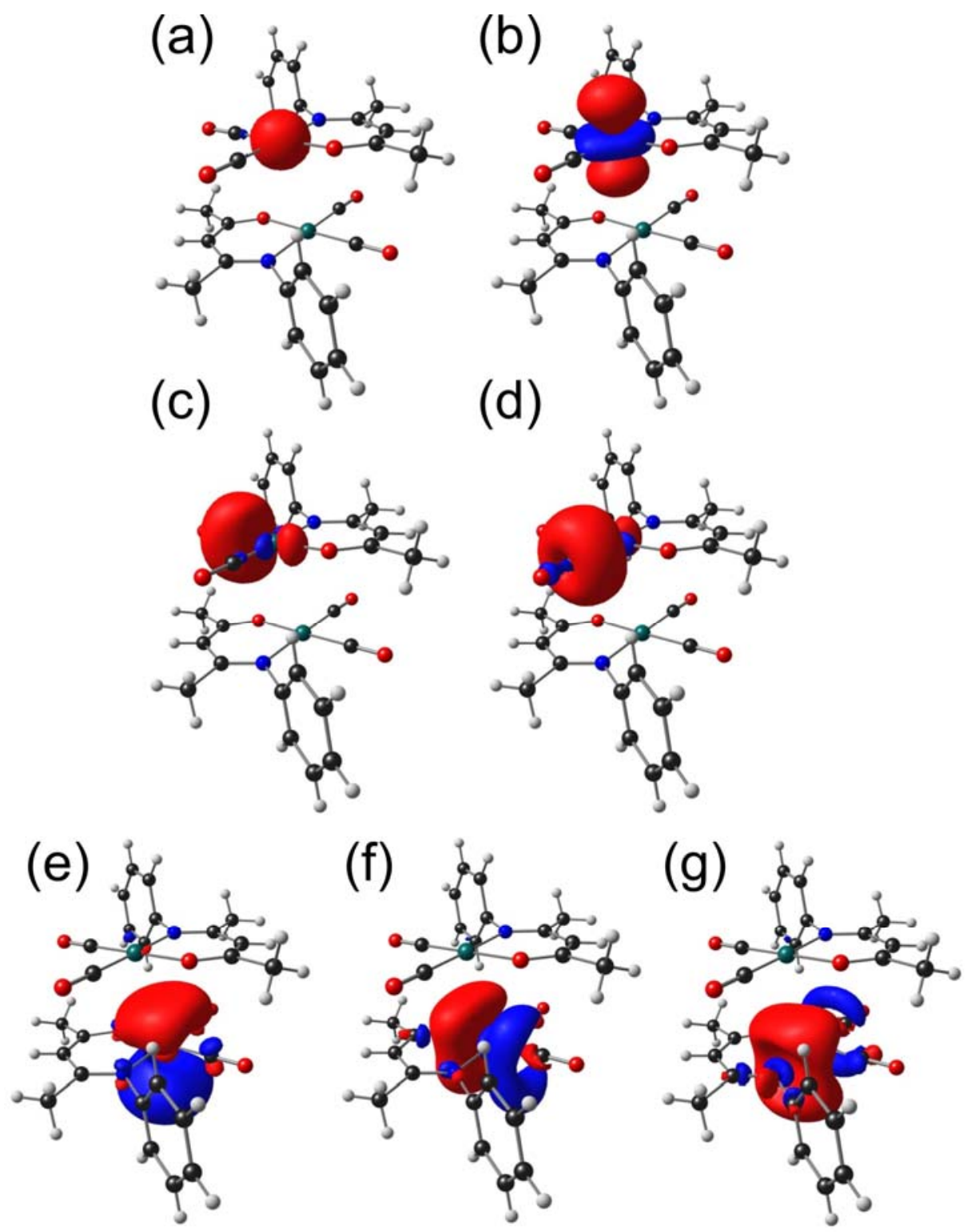

Figure 8: Selected natural bond orbitals of DFT single point 3 (coordinates of the $\beta$-polymorph at $100 \mathrm{~K}$, with a slight lateral shift of $0.310 \AA \AA$ between adjacent rhodium atoms). Donor NBOs: (a) LP on Rh is of mainly $s$ character, (b) LP on Rh is of mainly $d_{z^{2}}$ character, (c) BD (Rh-Ctrans o), (d) BD (Rh-Ctrans N). Acceptor NBOs: (e) LP* on Rh is of mainly $p_{z}$ character, (f) $\mathrm{LP}^{*}$ on $\mathrm{Rh}$ is of mainly $p_{\mathrm{y}}$ character and $(\mathrm{g}) \mathrm{LP}^{*}$ on $\mathrm{Rh}$ is of mainly $p_{\mathrm{x}}$ character. The NBO plots utilise a contour of $0.05 \mathrm{e} / \AA^{3}$. Colour code of atoms (online version): Rh (green), C (black), N (blue), O (red), H (white). 

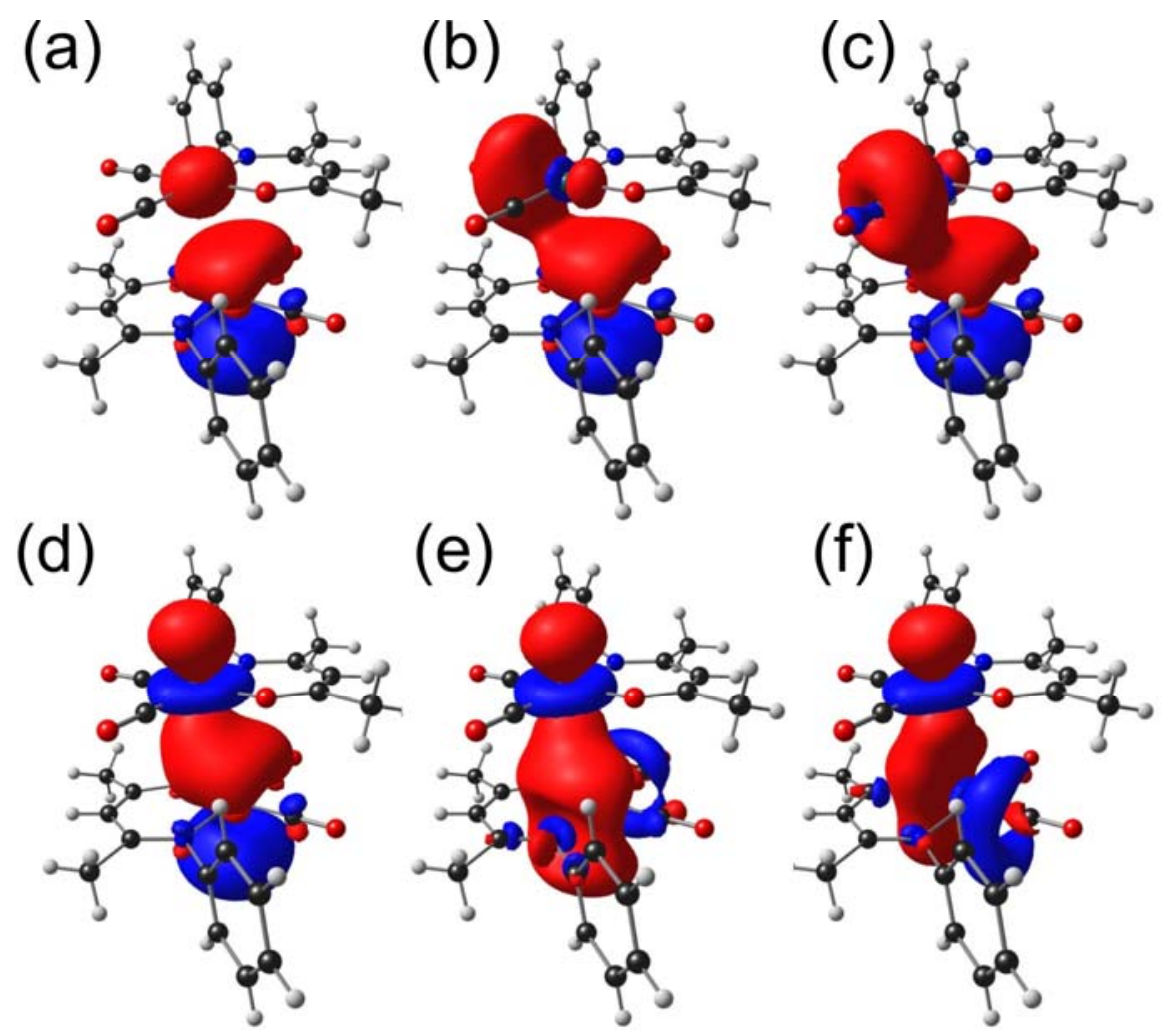

Figure 9: Visualisation of selected donor - acceptor NBO interactions between the two rhodium centres in bimolecular $\left[\mathrm{Rh}\left(\mathrm{CH}_{3} \mathrm{COCHCN}(\mathrm{Ph}) \mathrm{CH}_{3}\right)(\mathrm{CO})_{2}\right]_{2}$ of DFT single point 3 (coordinates of the $\beta$-polymorph at $100 \mathrm{~K}$, with a slight lateral shift of $0.310 \AA$ between adjacent rhodium atoms). (a) LP(Rh of mainly $s$ character) - LP*(Rh of mainly $p_{z}$ character), (b) LP(Rh of mainly $p_{z}$ character) - LP*(Rh of mainly $p_{y}$ character), (c) LP (Rh of mainly $p_{z}$ character) - LP*(Rh of mainly $p_{x}$ character), (d) LP (Rh of mainly $d_{z^{2}}$ character) - LP*(Rh of mainly $p_{z}$ character), (e) LP (Rh of mainly $d_{z^{2}}$ character) - LP*(Rh of mainly $p_{x}$ character) and (f) LP (Rh of mainly $d_{z^{2}}$ character $)-\mathrm{LP} *\left(\mathrm{Rh}\right.$ of mainly $p_{y}$ character $)$. The NBO plots utilise a contour of $0.05 \mathrm{e} / \AA^{3}$. Colour code of atoms (online version): Rh (green), C (black), N (blue), O (red), H (white).

\subsubsection{QTAIM}

The interaction between the two $\left[\mathrm{Rh}\left(\mathrm{CH}_{3} \mathrm{COCHCN}(\mathrm{Ph}) \mathrm{CH}_{3}\right)(\mathrm{CO})_{2}\right]$ mono nuclear units in dinuclear $\left[\mathrm{Rh}\left(\mathrm{CH}_{3} \mathrm{COCHCN}(\mathrm{Ph}) \mathrm{CH}_{3}\right)(\mathrm{CO})_{2}\right]_{2}$ was further analysed, using Bader's quantum theory of atoms in molecules (QTAIM) theory with selected topological parameters of the inter-molecular bond-paths for the four dimolecular $\left[\mathrm{Rh}\left(\mathrm{CH}_{3} \mathrm{COCHCN}(\mathrm{Ph}) \mathrm{CH}_{3}\right)(\mathrm{CO})_{2}\right]_{2}$ models of this study listed in Table 5. The topological analysis of the charge density $\rho(r)$ distribution, as well as the properties of the critical points (CPs) determined by QTAIM, provides a universal indicator of bonding between atoms [44]. For the DFT optimised dimer 1, the DFT single point 2, the DFT single point 3 and the DFT single point 4, a total amount of two, nine, nine and three inter-molecular 
bonds respectively, were identified via bond critical points, see Figure 10. Due to symmetry, half of the bond paths are identical to the other half, except for the rhodium-rhodium bond path.

No rhodium-rhodium bond path was identified for the DFT optimised dimer 1 with the largest lateral shift of $1.590 \AA$, indicating no formation of the linear metal-metal chains. However, the DFT optimised dimer 1 is stabilised by two inter-molecular hydrogen bonds, thereby favouring the formation of the observed dinuclear units in the solid state, as observed for the $\alpha$-polymorphs of this study.

For DFT single point 2, DFT single point 3 and DFT single point 4, in addition to inter-molecular hydrogen bonds, rhodium-rhodium bond paths was identified. The electron density $(\rho)$ and the Laplacian of electron density $\left(\nabla^{2} \rho\right)$ at the rhodium-rhodium bond critical point, increased in value in going from DFT single point 2 to DFT single point 3 and to DFT single point 4, corresponding to decreasing lateral shift: For example, electron density $(\rho)$ at the rhodium-rhodium bond critical point increased in the order 0.0113 e. $\mathrm{a}^{-3}<0.0160$ e. $\mathrm{a} 0^{-3}<0.1720$ e.a $0^{-3}$ from model 2 to model 4 , while the Laplacian of electron density $\left(\nabla^{2} \rho\right)$ increased accordingly, 0.0264 e. $\mathrm{a}^{-5}<0.0367$ e.a $0^{-5}<$ 0.0383 e.a $0^{-5}$, indicating a rhodium-rhodium bond path in the latter two models with much higher $\rho$ and $\nabla^{2} \rho$.

To conclude, both NBO and QTAIM calculations shed light on intermolecular interactions leading to the formation of dimeric $\left[\mathrm{Rh}\left(\mathrm{CH}_{3} \mathrm{COCHCN}(\mathrm{Ph}) \mathrm{CH}_{3}\right)(\mathrm{CO})_{2}\right]_{2}$ units as was found for both the $\alpha$ and $\beta$-polymorphs of this study. The rhodium-rhodium bond paths of the QTAIM results suggested the formation of wire-like rhodium-rhodium chains as the lateral shift between the two molecular units decreases as was found for the $\beta$-polymorphs of this study. 


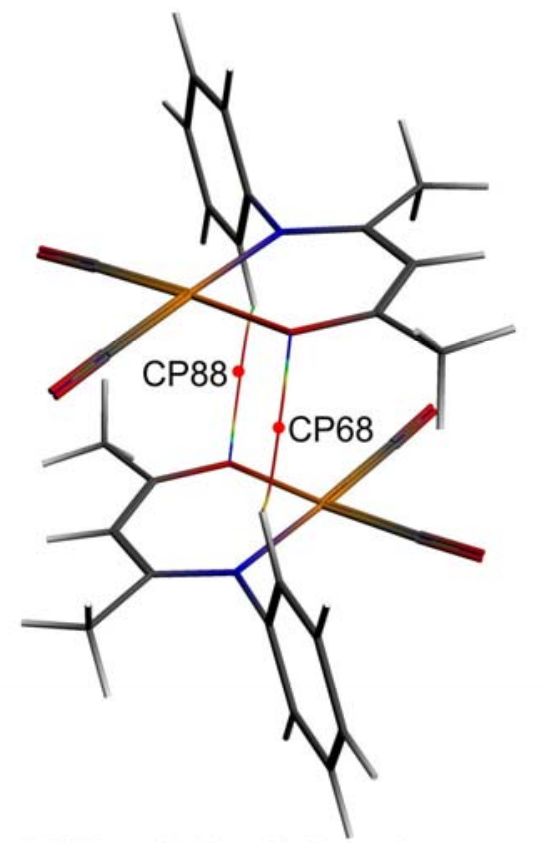

DFT optimized dimer1

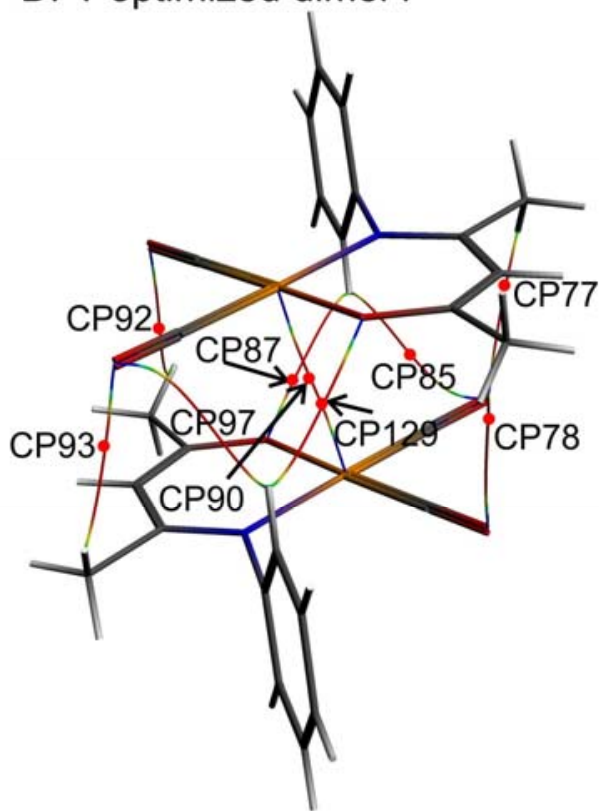

DFT single point 3
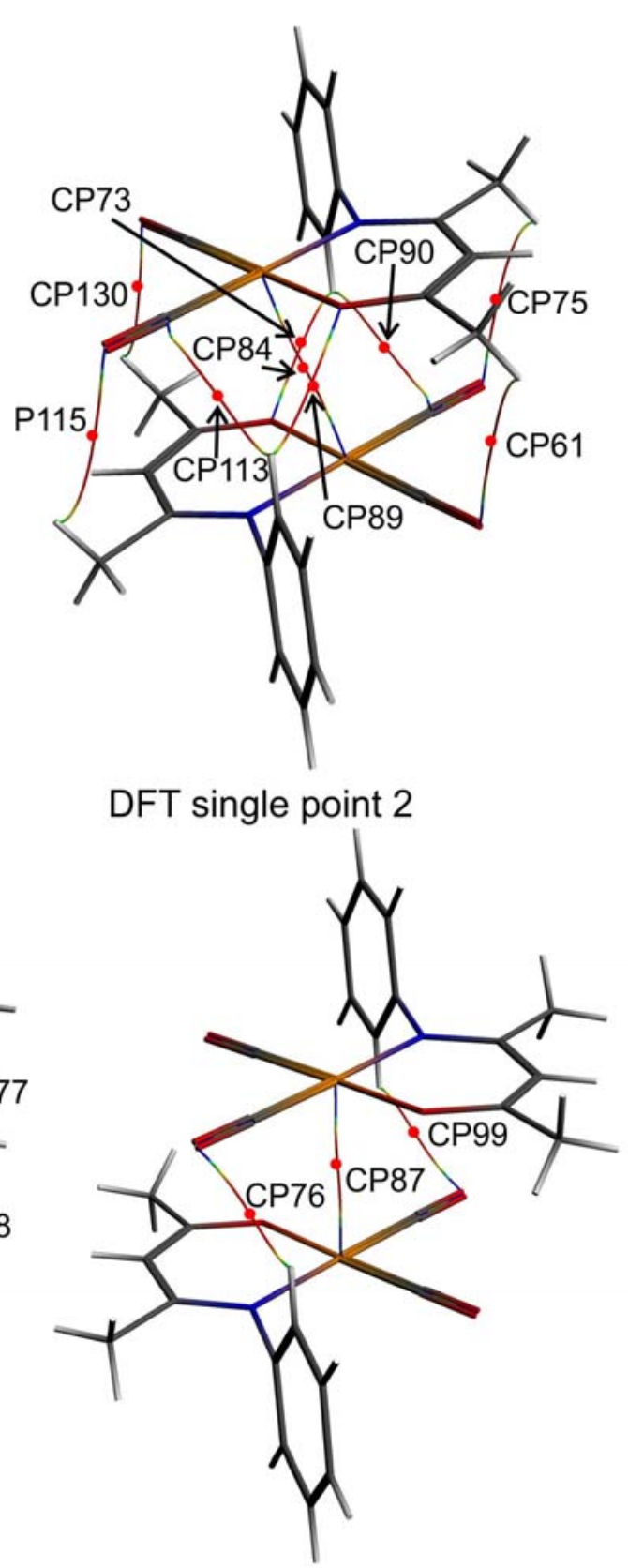

DFT single point 4

Figure 10: Schematic representation of the inter-molecular bond-paths (BP), indicated by red bond critical points (CP), which are present in the DFT optimised geometry of all four dimolecular $\left[\mathrm{Rh}\left(\mathrm{CH}_{3} \mathrm{COCHCN}(\mathrm{Ph}) \mathrm{CH}_{3}\right)(\mathrm{CO})_{2}\right]_{2}$ models of this study. The colour range of the bond-paths decreases in frequency, according to the value of the electron density: from blue (high density) to green to red (low density).

Table 5: Selected topological parameters of the inter-molecular bond-paths for the four dimolecular $\left[\mathrm{Rh}\left(\mathrm{CH}_{3} \mathrm{COCHCN}(\mathrm{Ph}) \mathrm{CH}_{3}\right)(\mathrm{CO})_{2}\right]_{2}$ models of this study, indicating that $\mathrm{Rh}-\mathrm{Rh}$ bond paths are only present for models 2 to 4 . The critical point (CP) numbers are shown in Figure 10. 


\begin{tabular}{lllllll}
\hline $\begin{array}{l}\text { Bond/Ring critical } \\
\text { point }\end{array}$ & Bond type & $\begin{array}{l}\text { Atoms } \\
\text { involved }\end{array}$ & $\begin{array}{l}\text { inter-atomic } \\
\text { distance } \\
/ \AA\end{array}$ & $\begin{array}{l}\text { BP } \\
\text { length } \\
/ \AA\end{array}$ & $\begin{array}{l}\text { Electron } \\
\text { density } \\
\rho / \mathrm{e} \mathrm{a}^{-3}\end{array}$ & $\begin{array}{l}\text { Laplacian of } \\
\text { electron density } \\
\nabla^{2} \rho / \mathrm{e} \mathrm{a}_{0}{ }^{-5}\end{array}$ \\
\hline $\begin{array}{l}\text { DFT optimised dimer } 1 \\
\text { CP \# 68/88 }\end{array}$ & hydrogen bond & O-H & 2.6314 & 2.6420 & 0.0062 & 0.0228 \\
$\begin{array}{l}\text { DFT single point } 2 \\
\text { CP \# 48 }\end{array}$ & rhodium-rhodium & Rh-Rh & 3.4811 & 3.4844 & 0.0113 & 0.0264 \\
CP \# 115/75 & hydrogen bond & O-H & 2.9315 & 3.0967 & 0.0034 & 0.0153 \\
CP \# 130/61 & hydrogen bond & O-H & 2.7761 & 2.8373 & 0.0046 & 0.0196 \\
CP \# 113/73 & carbon-hydrogen & C-H & 2.9478 & 3.0076 & 0.0033 & 0.0139 \\
CP \# 89/90 & hydrogen bond & O-H & 2.5858 & 2.6171 & 0.0071 & 0.0281 \\
DFT single point 3 & & & & & & \\
CP \# 90 & rhodium-rhodium & Rh-Rh & 3.3085 & 3.3109 & 0.0160 & 0.0367 \\
CP \# 93/77 & hydrogen bond & O-H & 2.7644 & 2.8699 & 0.0048 & 0.0213 \\
CP \# 92/78 & hydrogen bond & O-H & 2.9263 & 3.2006 & 0.0040 & 0.0181 \\
CP \# 9785 & hydrogen bond & O-H & 2.9244 & 3.1336 & 0.0041 & 0.0174 \\
CP \# 129/87 & hydrogen bond & O-H & 2.8607 & 2.9078 & 0.0041 & 0.0159 \\
DFT single point 4 & & & & & & \\
CP \# 87 & rhodium-rhodium & Rh-Rh & 3.3085 & 3.3097 & 0.1720 & 0.0383 \\
CP \# 76/99 & hydrogen bond & O-H & 2.4708 & 2.5016 & 0.0087 & 0.0382 \\
\hline
\end{tabular}

\section{Conclusion}

The geometry of the solid state structure of two $\left[\mathrm{Rh}\left(\mathrm{CH}_{3} \mathrm{COCHCN}(\mathrm{Ph}) \mathrm{CH}_{3}\right)(\mathrm{CO})_{2}\right]$ crystals presented in this contribution, compares well with the previously published structure [13] for the same complex, as well as with the DFT calculated optimised single molecular unit $\left[\mathrm{Rh}\left(\mathrm{CH}_{3} \mathrm{COCHCN}(\mathrm{Ph}) \mathrm{CH}_{3}\right)(\mathrm{CO})_{2}\right]$ from this study. Different crystallization conditions (solvent and temperature) led to different polymorphs ( $\alpha$ and $\beta$ ), with a difference in crystal packing of $\left[\mathrm{Rh}\left(\mathrm{CH}_{3} \mathrm{COCHCN}(\mathrm{Ph}) \mathrm{CH}_{3}\right)(\mathrm{CO})_{2}\right]$. The solid state crystallographic data of both the $\alpha$ - and $\beta$ polymorph $\left[\mathrm{Rh}\left(\mathrm{CH}_{3} \mathrm{COCHCN}(\mathrm{Ph}) \mathrm{CH}_{3}\right)(\mathrm{CO})_{2}\right]$ crystal structures, show that this complex forms dimeric units that either stacked in wire-like linear metal-metal chains ( $\beta$-polymorph) or the dimeric units do not stack onto each other ( $\alpha$-polymorph). Additional theoretical QTAIM computations supported the experimental crystallographic findings of dimer formation, since it was found that the DFT optimised dimer of $\left[\mathrm{Rh}\left(\mathrm{CH}_{3} \mathrm{COCHCN}(\mathrm{Ph}) \mathrm{CH}_{3}\right)(\mathrm{CO})_{2}\right]_{2}$ is stabilised by two inter-molecular hydrogen bonds, thereby favouring the formation of the observed dinuclear units in the solid state. QTAIM results further suggested the formation of wire-like rhodium-rhodium chains as the lateral shift between the two molecular units decreases as was found for the $\beta$-polymorphs of this study. An NBO analysis of the DFT optimised dinuclear $\left[\mathrm{Rh}\left(\mathrm{CH}_{3} \mathrm{COCHCN}(\mathrm{Ph}) \mathrm{CH}_{3}\right)(\mathrm{CO})_{2}\right]_{2}$ unit, showed that various donor-acceptor interactions between the two separate $\left[\mathrm{Rh}\left(\mathrm{CH}_{3} \mathrm{COCHCN}(\mathrm{Ph}) \mathrm{CH}_{3}\right)(\mathrm{CO})_{2}\right]$ molecules do favour the formation of dimeric $\left[\mathrm{Rh}\left(\mathrm{CH}_{3} \mathrm{COCHCN}(\mathrm{Ph}) \mathrm{CH}_{3}\right)(\mathrm{CO})_{2}\right]_{2}$ pairs. 


\section{Supporting Information}

Crystallographic data has been deposited at the Cambridge Crystallographic Data Centre with deposit numbers 1548178, 1558071, 1571132-1571134. Copies can be obtained, free of charge, on application to CCDC, 12 Union Road, Cambridge CB2 1EZ, UK [fax: +44 (0)1223 336033 or ww.ccdc.cam.ac.uk/products/csd/request/]. The optimised coordinates of the DFT calculations are given in the Supporting Information.

\section{Acknowledgements}

This work has received support from the South African National Research Foundation and the Central Research Fund of the University of the Free State, Bloemfontein, South Africa. The High Performance Computing facility of the University of the Free State, the Centre for High Performance Computing CHPC of South Africa and the Norwegian supercomputing program NOTUR (Grant No. NN4654K), are gratefully acknowledged for computer time. The authors wish to thank Prof M. Fernandes from the University of the Witwatersrand for the data collection at 100 $\mathrm{K}$ on the $\alpha$-polymorph.

\section{References}

[1] J. Bernstein, Polymorphism in molecular crystals, Oxford University Press, Oxford, 2002. ISBN: 9780199236565 DOI:10.1093/acprof:oso/9780199236565.001.0001

[2] W.C. McCrone, Polymorphism, in: D. Fox, M.M. Labes, A. Weissberger (Eds.) Physics and chemistry of the organic solid state, Vol. 2, Wiley Interscience, New York, USA, 1965, pp. 725-67. [3] S. Rosenstein, P.P. Lamy, Some aspects of polymorphism, American Journal of Hospital Pharmacy 26 (1969) 598-601. PMID: 5345852

[4] E.M. Gussenhoven, M.M. Olmstead, J.C. Fettinger, A.L. Balch, Interplay of Supramolecular Organization, Metallophilic Interactions, Phase Changes, and Luminescence in Four Polymorphs of $\operatorname{IrI}(\mathrm{CO})_{2}\left(\mathrm{OC}\left(\mathrm{CH}_{3}\right) \mathrm{CHC}\left(\mathrm{CH}_{3}\right) \mathrm{N}(\mathrm{p}\right.$-tol $\left.)\right), \quad$ Inorganic Chemistry $47 \quad$ (2008) 4570-4578. DOI:10.1021/ic702243z

[5] K.H. Hopmann, N.F. Stuurman, A. Muller, J. Conradie, Substitution and Isomerisation of Asymmetric $\beta$-Diketonato Rhodium (I) Complexes: A Crystallographic and Computational Study, Organometallics 29 (2010) 2446-2458. DOI: 10.1021/om1000138 
[6] N.F. Stuurman, R, Meijboom, J. Conradie, Characterization of [ $\left.\mathrm{Rh}\left(\mathrm{PhCOCHCOCH}_{2} \mathrm{CH}_{2} \mathrm{CH}_{3}\right)(\mathrm{CO})_{2}\right]$ by X-ray Crystallography, a Computational and a Statistical Study, Polyhedron 30 (2011) 660-665. DOI: 10.1016/j.poly.2010.11.038

[7] J. Conradie, T.S. Cameron, M.A.S. Aquino, G.J. Lambrecht, J.C. Swarts, Synthetic, electrochemical and structural aspects of a series of ferrocene-containing dicarbonyl betadiketonato rhodium(I) complexes, Inorganica Chimica Acta $358 \quad$ (2005) 2530-2542. DOI:10.1016/j.ica.2005.02.010

[8] M.M. Conradie, J. Conradie, Solid state packing of [Rh( $\beta$-diketonato $\left.)(\mathrm{CO})_{2}\right]$ complexes. Crystal structure of $\left[\mathrm{Rh}\left(\mathrm{PhCOCHCOC}_{4} \mathrm{H}_{3} \mathrm{~S}\right)(\mathrm{CO})_{2}\right]$, Journal of Molecular Structure 1051 (2013) 137-143. DOI: 10.1016/j.molstruc.2013.07.046

[9] C. Pretorius, A. Roodt, (Benzoyl-acetonato- $\kappa^{2} \mathrm{O}, \mathrm{O}^{\prime}$ )dicarbonyl-rhodium(I), Acta Crystallographica E68 (2012) m1451-m1452. DOI: 10.1107/S1600536812044893

[10] J.G. Leipoldt, L.D.C. Bok, S.S. Basson, J.S. van Vollenhoven, T.I.A. Gerber, The crystal structure of benzoyl-1,1,1-trifluoroacetonatodicarbonylrhodium(I), Inorganica Chimica Acta 25 (1977) L63-L64. DOI: 10.1016/S0020-1693(00)95646-9

[11] M.M. Conradie, P.H. van Rooyen, C. Pretorius, , A. Roodt, J. Conradie, Rhodium-rhodium interactions in $\left[\mathrm{Rh}(\beta\right.$-diketonato $\left.)(\mathrm{CO})_{2}\right]$ complexes, Journal of Molecular Structure, (2017) DOI: 10.1016/j.molstruc.2017.04.113.

[12] N.A. Bailey, E. Coates, G.B. Robertson, F. Bonati, R. Ugo, The Crystal and Molecular Structures of Acetylacetonatobiscarbonylrhodium(I) and of Some Fluoro-substituted Complexes, Chemical Communications (1967) 1041-1042. DOI: 10.1039/C19670001041

[13] G.J.S. Venter, G. Steyl, A. Roodt, Solid state and theoretical study of structural properties induced by step-wise chloro functionalization in dicarbonyl-[2-(phenylamino)pent-3-en-4onato]rhodium(I) complexes, Journal of Coordination Chemistry 67 (2014) 176-193. DOI:10.1080/00958972.2013.878801

[14] A.F. Dove, V.C. Gibson, E.L. Marshall, A.J.P. White, D.J. Williams, Magnesium and zinc complexes of a potentially tridentate $\beta$-diketiminate ligand, Journal of the Chemical Society, Dalton Transactions (2004) 570-578. DOI:10.1039/B314760F

[15] J.E. Parks, R.H. Holm, Synthesis, solution stereochemistry, and electron delocalization properties of bis( $\beta$-iminoamino)nickel(II) complexes, Inorganic Chemistry 7 (1968) 1408-1416. DOI:10.1021/ic50065a029

[16] P.H.M. Budzelaar, N.N.P. Moonen, R. De Gelder, J.M.M. Smits, A.W. Gal, Rhodium and Iridium $\beta$-Diiminate Complexes - Olefin Hydrogenation Step by Step, European Journal of 
Inorganic Chemistry (2000) 753-769. DOI: 10.1002/(SICI)1099-0682(200004)2000:4<753::AIDEJIC753>3.0.CO;2-V

[17] M.J. Lacey, Convenient syntheses of 4-Aminopent-3-en-2-one and its copper and nickel complexes, Australian Journal of Chemistry 23 (1970) 841-842. DOI: 10.1071/CH9700841

[18] F. Bonati, G. Wilkinson, Dicarbonyl- $\beta$-diketonato- and related complexes of rhodium(I), Journal of the Chemical Society (1964) 3156-3160. DOI: 10.1039/JR9640003156

[19] APEX2 (including SAINT and SADABS), Bruker AXS Inc., Madison, WI, 2012.

[20] G.M. Sheldrick, A short history of SHELX, Acta Crystallographica A64 (2008) 112-122. DOI:10.1107/S0108767307043930

[21] A.D. Becke, Density-functional exchange-energy approximation with correct asymptotic behavior, Physical Review A 38 (1988) 3098-3100. DOI: 10.1103/PhysRevA.38.3098

[22] C.T. Lee, W.T. Yang, R.G. Parr, Development of the Colle-Salvetti correlation-energy formula into a functional of the electron density, Physical Review B 37 (1988) 785-789. DOI:10.1103/PhysRevB.37.785

[23] M.J. Frisch, G.W. Trucks, H.B. Schlegel, G.E. Scuseria, M.A. Robb, J.R. Cheeseman, G. Scalmani, V. Barone, B. Mennucci, G.A. Petersson, H. Nakatsuji, M. Caricato, X. Li, H.P. Hratchian, A.F. Izmaylov, J. Bloino, G. Zheng, J.L. Sonnenberg, M. Hada, M. Ehara, K. Toyota, R. Fukuda, J. Hasegawa, M. Ishida, T. Nakajima, Y. Honda, O. Kitao, H. Nakai, T. Vreven, J.A. Montgomery (Jr), J.E. Peralta, F. Ogliaro, M. Bearpark, J.J. Heyd, E. Brothers, K.N. Kudin, V.N. Staroverov, T. Keith, R. Kobayashi, J. Normand, K. Raghavachari, A. Rendell, J.C. Burant, S.S. Iyengar, J. Tomasi, M. Cossi, N. Rega, J.M. Millam, M. Klene, J.E. Knox, J.B. Cross, V. Bakken, C. Adamo, J. Jaramillo, R. Gomperts, R.E. Stratmann, O. Yazyev, A.J. Austin, R. Cammi, C. Pomelli, J.W. Ochterski, R.L. Martin, K. Morokuma, V.G. Zakrzewski, G.A. Voth, P. Salvador, J.J. Dannenberg, S. Dapprich, A.D. Daniels, O. Farkas, J.B. Foresman, J.V. Ortiz, J. Cioslowski, D.J. Fox, Gaussian 09, Revision D.01, Gaussian Inc., Wallingford CT, 2010.

[24] F. Weigend, R. Ahlrichs, Balanced basis sets of split valence, triple zeta valence and quadruple zeta valence quality for $\mathrm{H}$ to Rn: Design and assessment of accuracy, Physical Chemistry Chemical Physics 7 (2005) 3297-3305. DOI: 10.1039/B508541A

[25] E.D. Glendening, J.K. Badenhoop, A.E. Reed, J.E. Carpenter, J.A. Bohmann, C.M. Morales, F. Weinhold, NBO 3.1, Theoretical Chemistry Institute, University of Wisconsin, Madison, WI, USA, 2001.

[26] R.F.W. Bader, A quantum theory of molecular structure and its applications, Chemical Reviews 91 (1991) 893-928. DOI: 10.1021/cr00005a013 
[27] F. Cortés-Guzmán, R.F.W. Bader, Complementarity of QTAIM and MO theory in the study of bonding in donor-acceptor complexes, Coordination Chemistry Reviews 249 (2005) 633-662. DOI:10.1016/j.ccr.2004.08.022

[28] J.I. Rodríguez, R.F.W. Bader, P.W. Ayers, C. Michel, A.W. Götz, C. Bo, A high performance grid-based algorithm for computing QTAIM properties, Chemical Physics Letters 472 (2009) 149152. DOI:10.1016/j.cplett.2009.02.081

[29] G. te Velde, F.M. Bickelhaupt, S.J.A. van Gisbergen, C.F. Guerra, E.J. Baerends, J.G. Snijders, T. Ziegler, Chemistry with ADF, Journal of Computational Chemistry 22 (2001) 931-967. DOI: $10.1002 /$ jcc. 1056

[30] C. Fonseca Guerra, J.G. Snijders, G. te Velde and E.J. Baerends, Towards an order-N DFT method, Theoretical Chemistry Accounts 99 (1998) 391-403. DOI:10.1007/s002140050353

[31] ADF2013, SCM, Theoretical Chemistry, Vrije Universiteit, Amsterdam, The Netherlands, 2013. http://www.scm.com

[32]. E.S. Vikulova, I.Y. Ilyin, K.I. Karakovskaya, D.A. Piryazev, N.B. Morozova, Crystal structure and thermal properties of $(1,1,1,5,5,5$-hexafluoropentanoato-4) • (dicarbonyl)iridium(I), Journal of Structural Chemistry 56 (2015) 1212-1214. DOI: 10.1134/S0022476615060335

[33] H. Huang, N.R. Hurubeanu, C.J. Bourgeois, S.-M. Cheah, J. Yuan, A.L. Rheingold, R.P. Hughes, Octahedral perfluoroalkyl complexes of $\operatorname{Ir}(\mathrm{III})$ formed by oxidative addition of perfluoroalkyl iodides to $\operatorname{Ir}(\mathrm{acac})(\mathrm{CO})_{2}$, Canadian Journal of Chemistry 87 (2009) 151-160. DOI: 10.1139/v08-114

[34] K.V. Zherikova, N.V. Kuratieva, N.B. Morozova, Crystal structure of (acetylacetonato) (dicarbonyl)iridium(I), Journal of Structural Chemistry 50 (2009) 574-576. DOI: 10.1007/s10947009-0088-X

[35] F. Huq, A.C. Skapski, Refinement of the crystal structure of acetylacetonatodicarbonylrhodium(I), Journal of Crystal and Molecular Structure 4 (1974) 411-418. DOI: 10.1007/BF01220097

[36] W.J. Hehre, A Guide to Molecular Mechanisms and Quantum Chemical Calculations, Wavefunction Inc., Irvine, CA, USA, 2003, pp. 153,181.

[37] M.M. Conradie, J. Conradie, Methyl Iodide Oxidative Addition to Rhodium(I) Complexes: a DFT and NMR Study of $\left[\mathrm{Rh}\left(\mathrm{FcCOCHCOCF}_{3}\right)(\mathrm{CO})\left(\mathrm{PPh}_{3}\right)\right]$ and the Rhodium(III) Reaction Products, South African Journal of Chemistry 61 (2008) 102-111.

[38] M.M. Conradie, J. Conradie, Stereochemistry of the Reaction Products of the Oxidative Addition Reaction of Methyl Iodide to $\left[\mathrm{Rh}\left(\left(\mathrm{C}_{4} \mathrm{H}_{3} \mathrm{~S}\right) \mathrm{COCHCOR}\right)(\mathrm{CO})\left(\mathrm{PPh}_{3}\right)\right]$ : a NMR and 
Computational Study. $\mathrm{R}=\mathrm{CF}_{3}, \mathrm{C}_{6} \mathrm{H}_{5}, \mathrm{C}_{4} \mathrm{H}_{3} \mathrm{~S}$, Inorganica Chimica Acta 362 (2009) 519-530. DOI:10.1016/j.ica.2008.04.046

[39] M.M. Conradie, J. Conradie, A Density Functional Theory Study of the Oxidative Addition of Methyl Iodide to Square Planar $\left[\mathrm{Rh}(\mathrm{acac})\left(\mathrm{P}(\mathrm{OPh})_{3}\right)_{2}\right]$ complex and simplified model systems, Journal of Organometallic Chemistry $695 \quad$ (2010) 2126-2133. DOI:10.1016/j.jorganchem.2010.05.021

[40] J. Conradie, Stacking of dicarbonylacetylacetonatorhodium(I) molecules, Computational and Theoretical Chemistry 1101 (2017) 30-35. DOI: 10.1016/j.comptc.2016.12.024

[41] J. Conradie, A comparative DFT study of stacking interactions between adjacent metal atoms in linear chains of Ir and Rh acetylacetonato complexes, Journal of Organometallic Chemistry, 833 (2017) 88-94. DOI: 10.1016/j.jorganchem.2017.01.032

[42] F. Weinhold, A.E. Reed, Natural Bond Orbitals and Extensions of Localized Bonding Concepts, Chemistry Education: Research and Practice in Europe 2 (2001) 91-104. DOI:10.1039/B1RP90011K

[43] A.E. Reed, L.A. Curtiss, F. Weinhold, Intermolecular interactions from a natural bond orbital, donor-acceptor viewpoint, Chemical Reviews 88 (1988) 899-926. DOI: 10.1021/cr00088a005

[44] R.F.W. Bader, A Bond Path: A Universal Indicator of Bonded Interactions, Journal of Physical Chemistry A 102 (1998) 7314-7323. DOI: 10.1021/jp981794v 